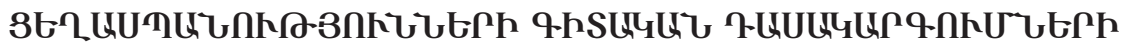

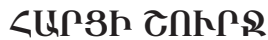

\author{
Unipliu U. Uiuiniljuin

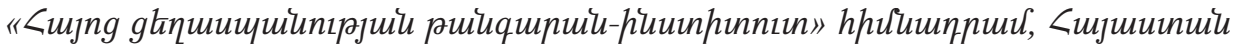

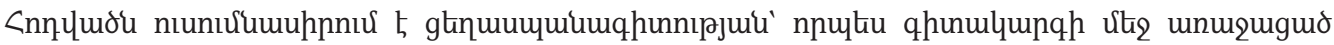

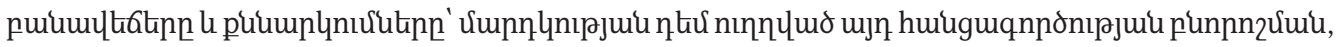

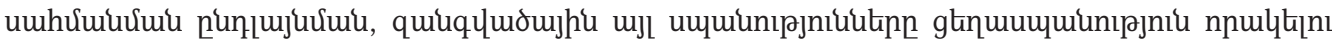

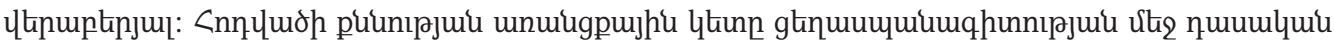

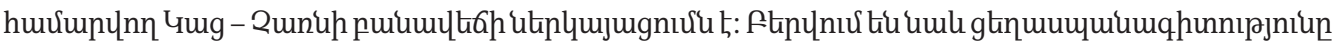

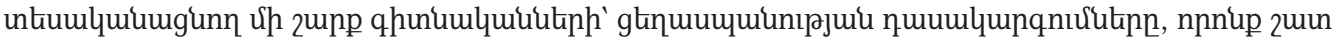

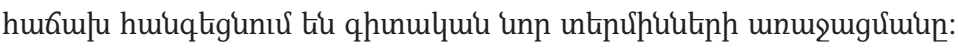

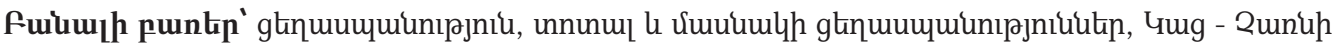

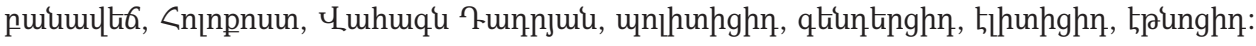

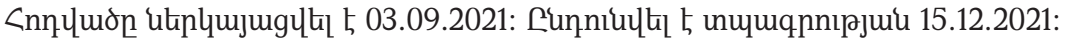

The article was submitted on 03.09.2021 and accepted for publication on 15.12.2021.

Статья поступила 03.09.2021 и была принята к публикации 15.12.2021.

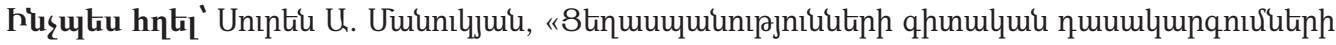

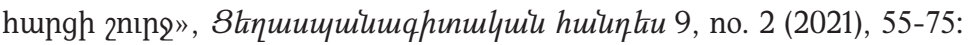

How to cite: Suren A. Manukyan, "On the Academic Classifications of Genocides," Ts'eghaspanagitakan handes 9, no. 2 (2021): 55-75.

Как ссылаться: Сурен А. Манукян, “К вопросу об академических классификациях геноцидов,” Тсехаспанагитакан андес 9, по. 2 (2021): 55-75.

\section{Utipuonıpjnil}

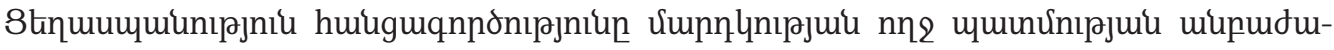

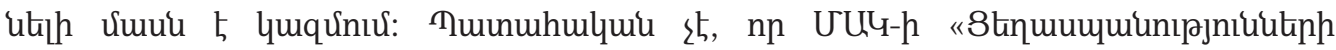

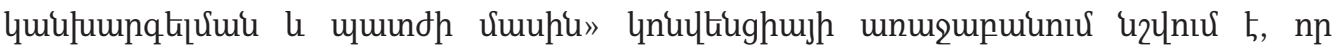

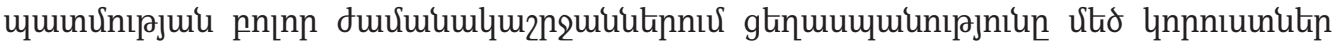

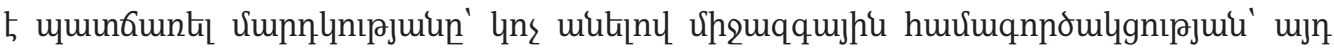
unhulhnphg uquunltipn hưर्un:

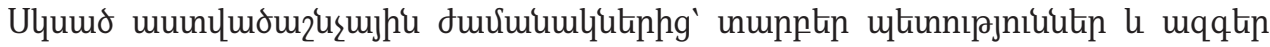

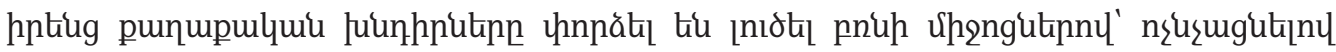

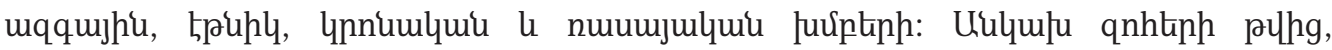

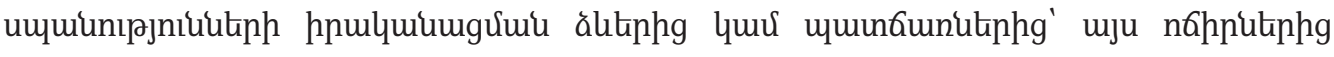




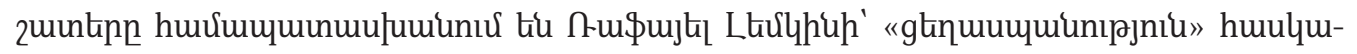
gnıрjui punnnzumuñ 1 :

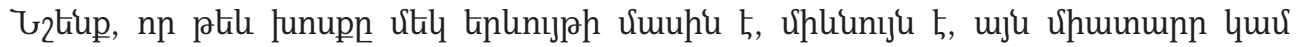

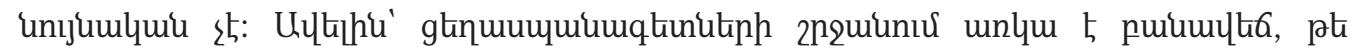

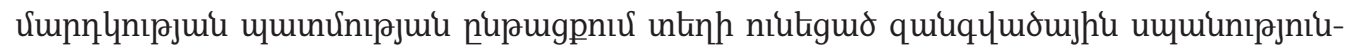

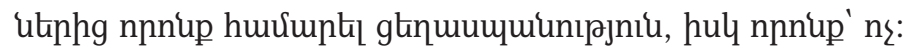

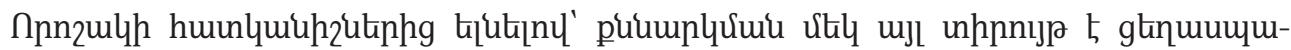

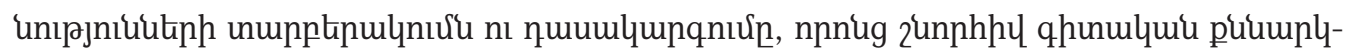

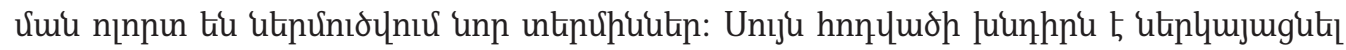

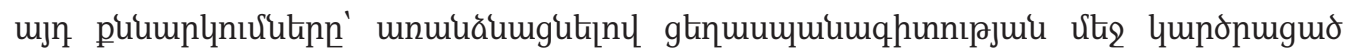
nnn2 untumlkinutip:

\section{Gug - 2un'th puiuulth6p}

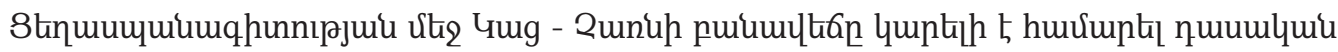

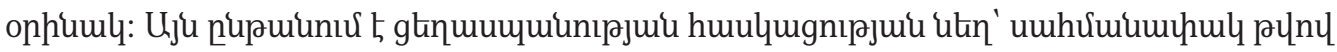

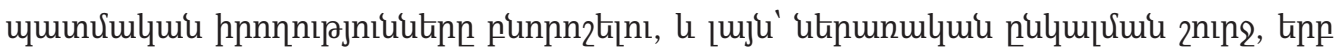

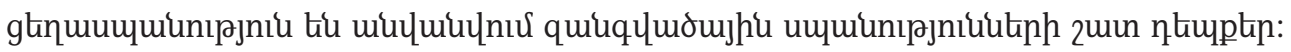

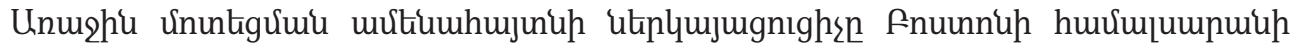

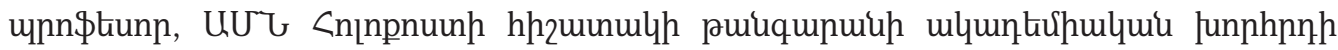

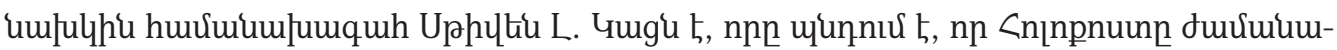

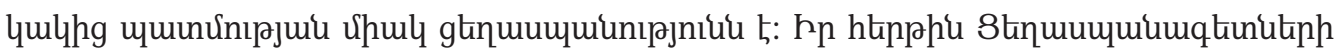

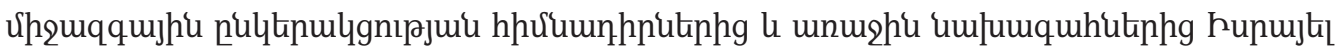

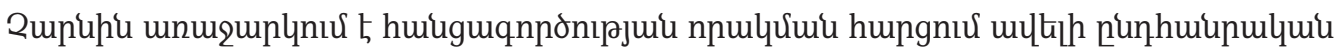

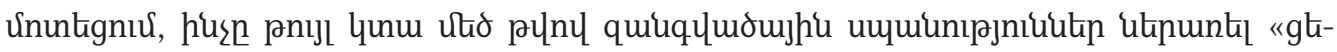

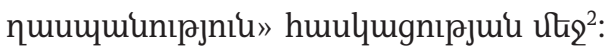

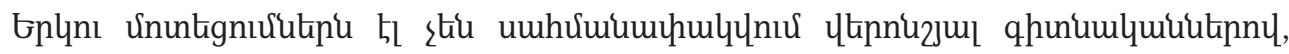

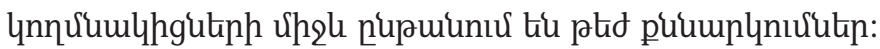

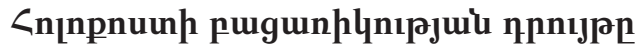

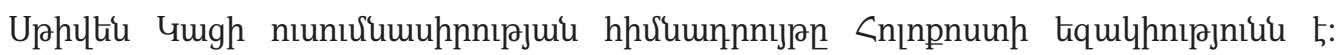

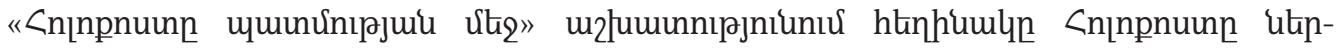

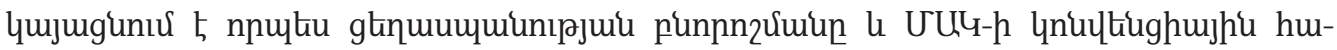

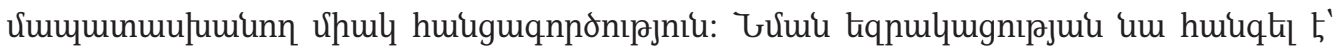

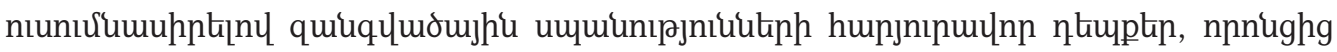

1 Gưuu onhumulukph umuhu untiu Ben Kiernan, Blood and Soil: A World History of Genocide and Extermination from Sparta to Darfur (New Haven: Yale University Press, 2007); Norman M. Naimark, Genocide: A World History (Oxford: Oxford University Press, 2017) .

2 Daniel Feierstein, "Leaving the Parental Home: An Overview of the Current State of Genocide Studies," Genocide Studies and Prevention 6, no. 3 (2011): 258. 


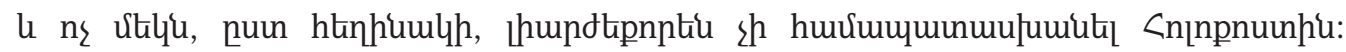

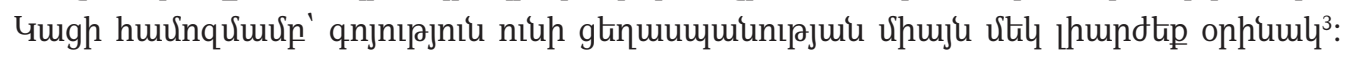

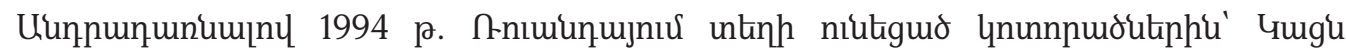

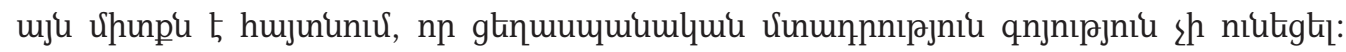

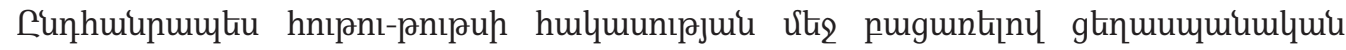

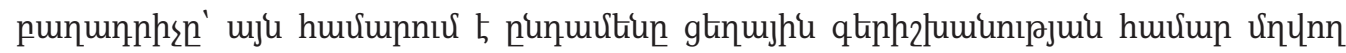

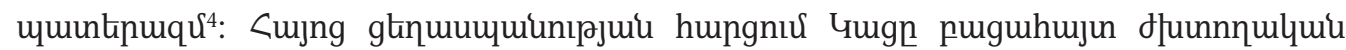

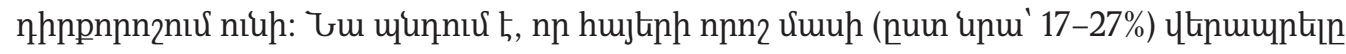

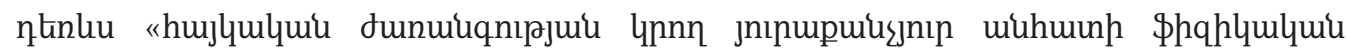

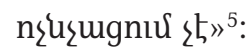

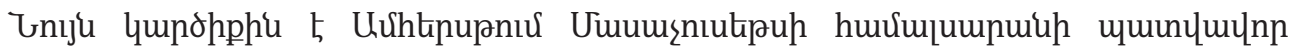

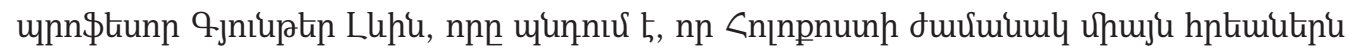

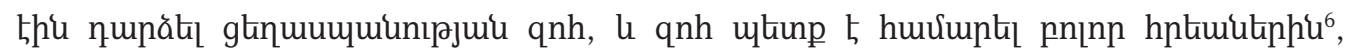

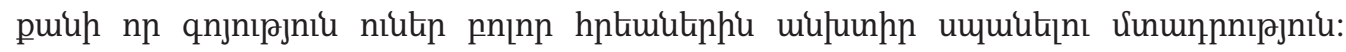

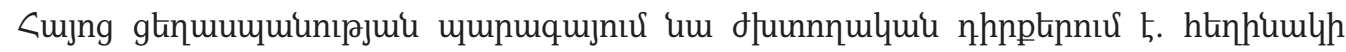

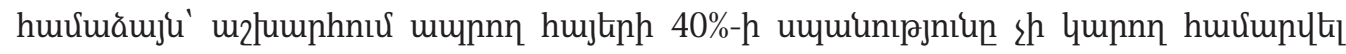

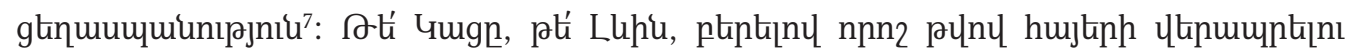

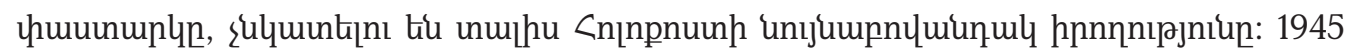

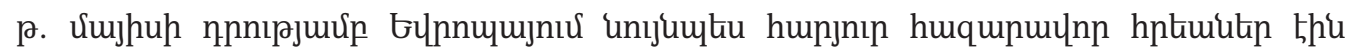

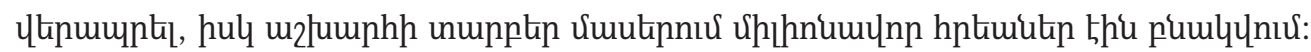

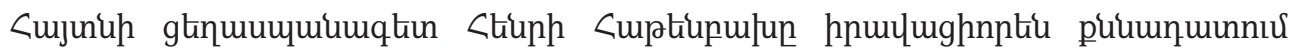

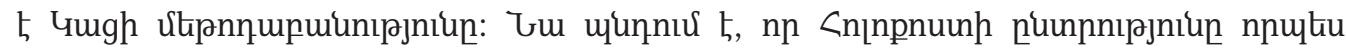

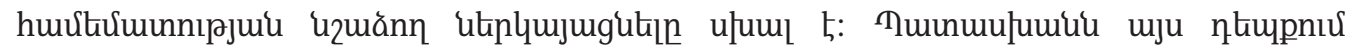

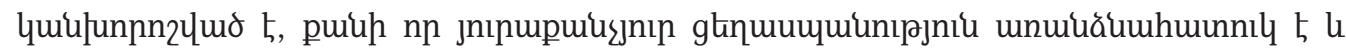

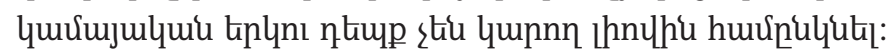

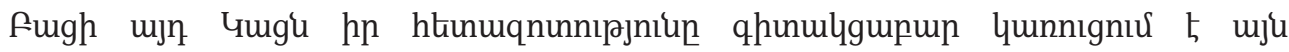

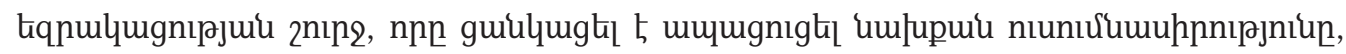

3 Steven T. Katz, The Holocaust in Historical Context. Volume I. The Holocaust and Mass Death before the Modern Age (New York: Oxford University Press, 1994).

4 Liz McMillin, "The Uniqueness of the Holocaust," in Chronicle of Higher Education, http://chronicle.com/ article/The-Uniqueness-of-the/90491/, nhunltıl 5 27.08.2021; David Stannard, "Uniqueness as Denial: The Politics of Genocide Scholarship," in Is the Holocaust Unique? Perspectives on Comparative Genocide, ed. Alan Rosenbloom (Boulder, CO: Westview, 2009).

5 Steven Katz, "Uniqueness: The Historical Dimension," in Is the Holocaust Unique? 69; Steven Katz, "The 'Unique' Intentionality," 175-176; Hannibal Travis, "On the Original Understanding of the Crime of Genocide," Genocide Studies and Prevention 7, no. 1 (2012): 32.

6 Guenter Lewy, The Nazi Persecution of the Gypsies (Oxford: Oxford University Press, 2000), 225-226.

7 Guenter Lewy, "The First Genocide of the 20th Century? (Armenian Massacres, 1915-1916)," December 2005, https://www.commentary.org/articles/guenter-lewy/the-first-genocide-of-the-20th-century/, nhun-

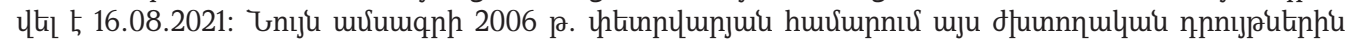

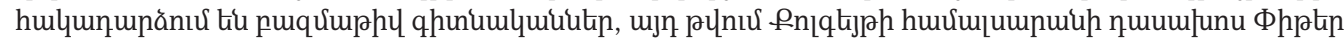

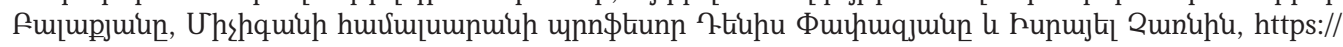
www.commentary.org/articles/reader-letters/genocide/, nhunltıl 5 16.08.2021: 


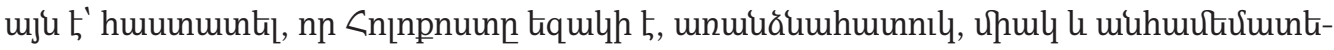

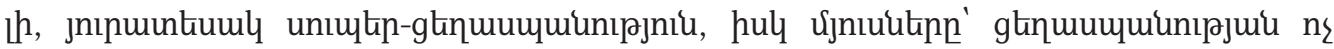

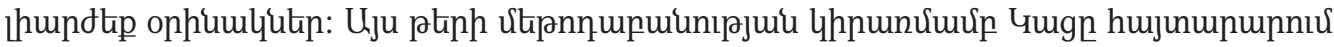

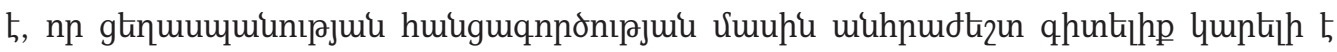

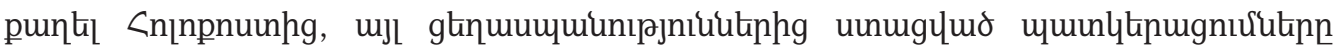
knlnnnnulqui tü:

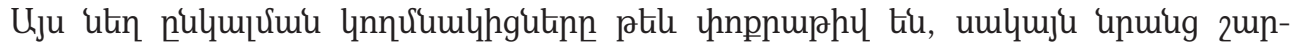

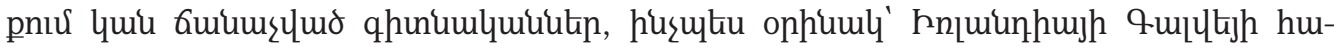

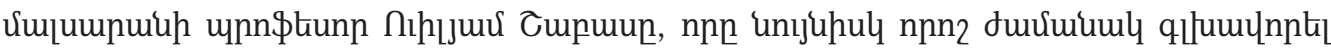

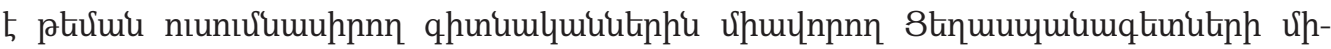

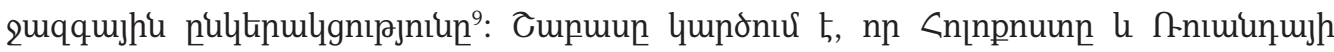

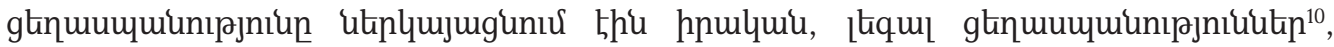

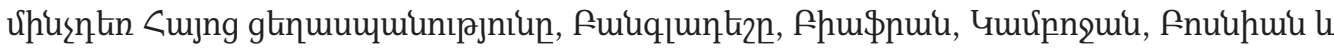

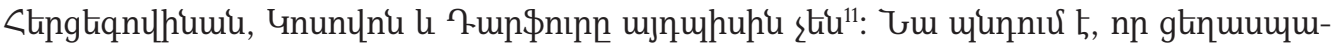

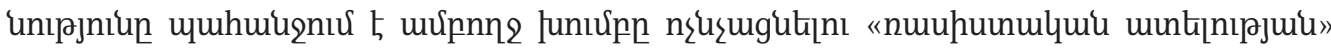

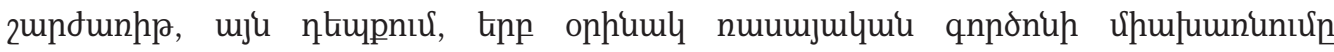

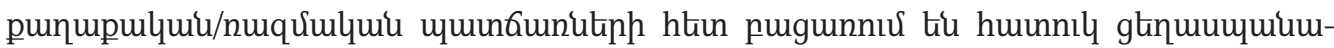
quiu Uumunnnıpjniup ${ }^{12}$ :

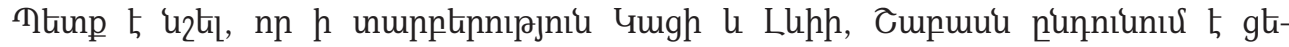

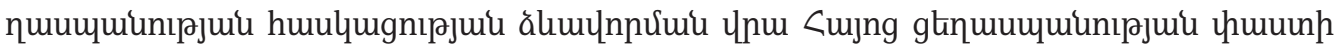
uqqügnipjniú ${ }^{13}$ :

8 Henry R. Huttenbach, "From the Editor: Towards a Conceptual Definition of Genocide," Journal of Genocide Research 4, no. 2 (2002):168.

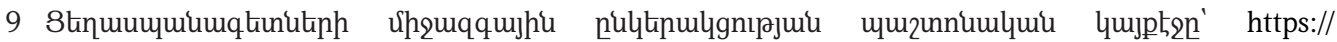

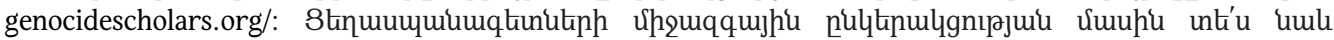

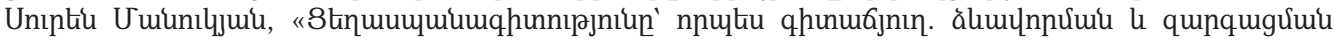

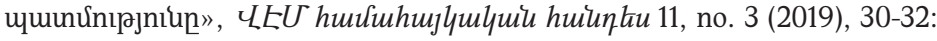

10 William Schabas, "Problems of International Codification - were the Atrocities in Cambodia and Kosovo Genocide?" New England Law Review 35, no. 2 (2001): 287-302, 296, 301-302; William Schabas, "Was Genocide Committed in Bosnia and Herzegovina? First Judgments of the International Criminal Tribunal for the Former Yugoslavia," Fordham International Law Journal 25, no. 1 (2001): 23-53, 45-47; William Schabas, "National Courts Finally Begin to Prosecute Genocide, the 'Crime of Crimes," Journal of International Criminal Justice 1, no 1 (2003): 39-63, 39, 41, 45, 55, 58; William Schabas, "The Jelisic Case and the Mens Rea of the Crime of Genocide," Leiden Journal of International Law 14, no. 1 (2001): 125-139; William Schabas, "Genocide Law in a Time of Transition: Recent Developments in the Law of Genocide," Rutgers Law Review 61, no. 1 (2008): 161-192; Travis, "On the Original Understanding of the Crime of Genocide," 32.

11 William Schabas, Genocide in International Law (Cambridge: Cambridge University Press, 2009), 102.

12 William Schabas, "State Policy as an Element of International Crimes," Journal of Criminal Law and Criminology 98, no. 3 (2008): 953-982, 970-971; Travis, "On the Original Understanding of the Crime of Genocide," 32.

13 ษnıju untূnnu, 36: 


\section{Uthpunulyuit ưnuntignıup}

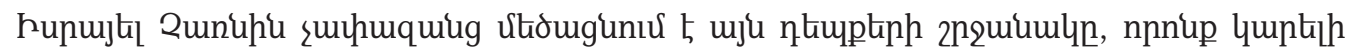

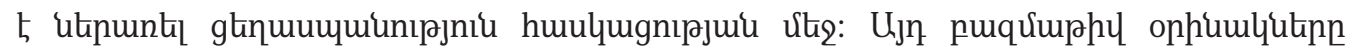

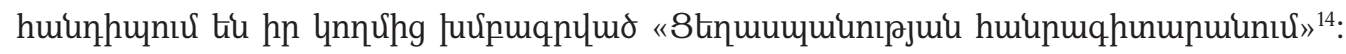

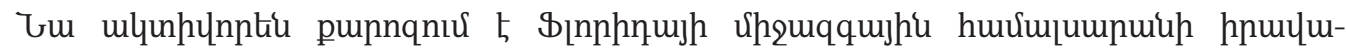

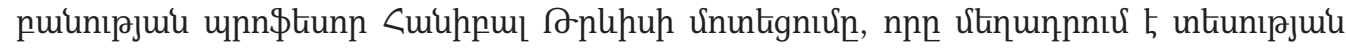

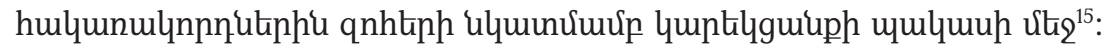

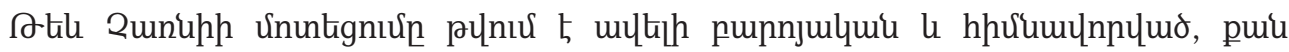

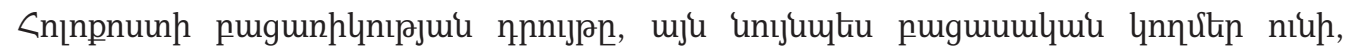

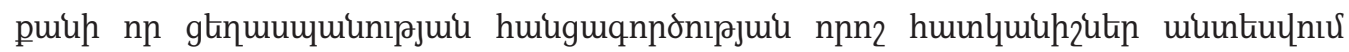

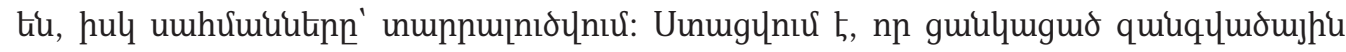

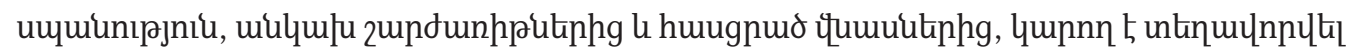

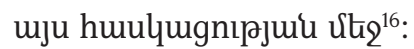

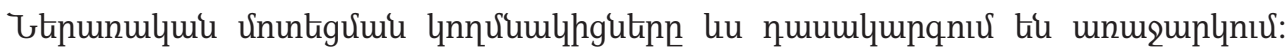

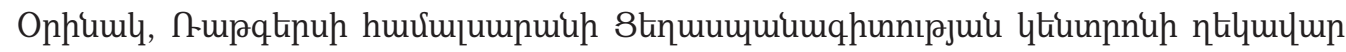

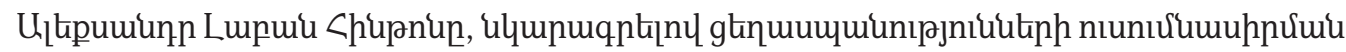

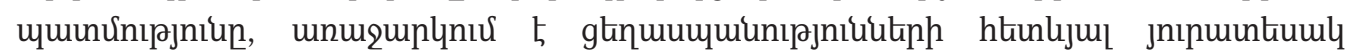

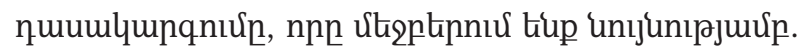

w) Gulumunhu' Cnnnpnuin,

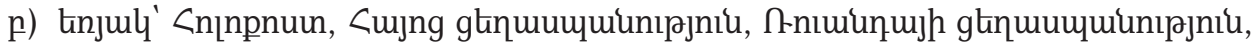

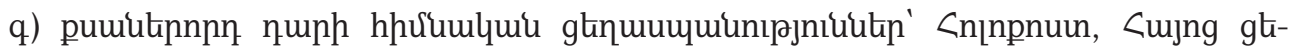

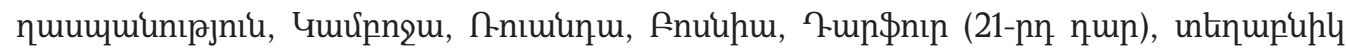

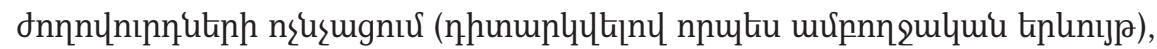

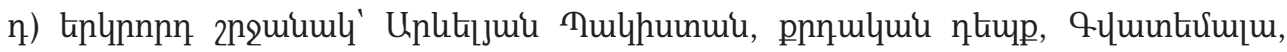

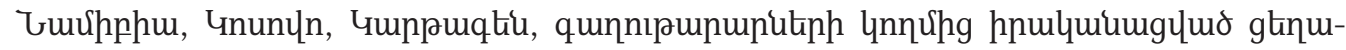

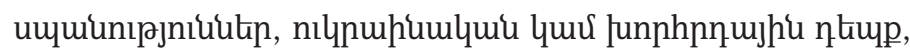

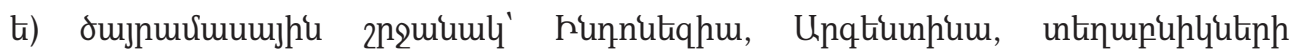

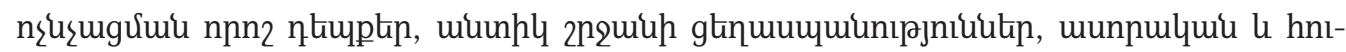

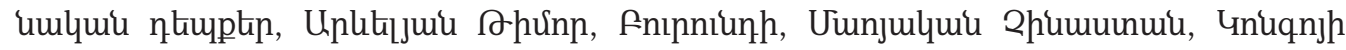

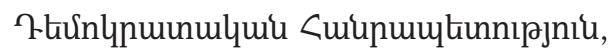

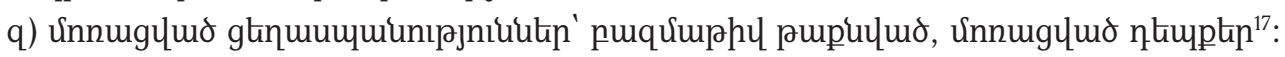

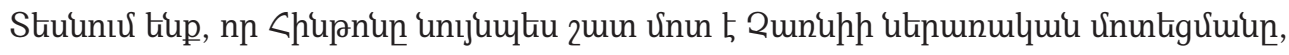
umluuju unnnănıর

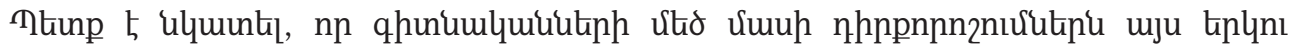

14 Encyclopedia of Genocide, ed. Israel Charny (Santa Barbara, CA: ABC-CLIO, 2000).

15 Travis, "On the Original Understanding of the Crime of Genocide," 30-55.

16 Huttenbach, "Towards a Conceptual Definition of Genocide," 169.

17 Alexander Laban Hinton, "Critical Genocide Studies," Genocide Studies and Prevention 7, no. 1 (2012): 13. 


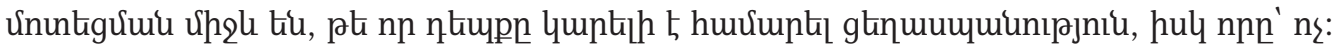

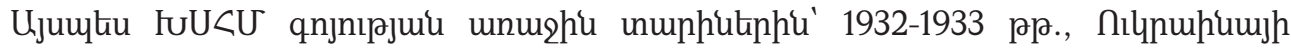

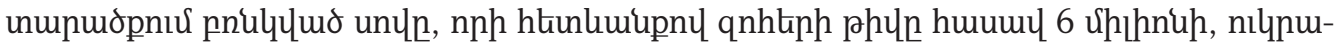

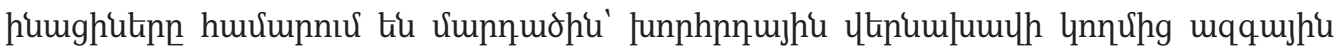

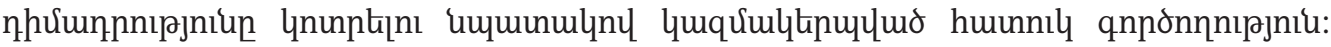

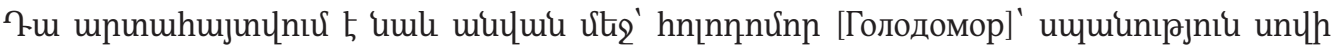

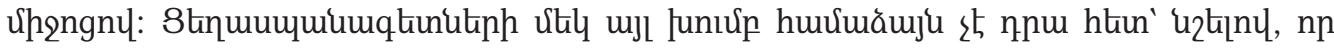

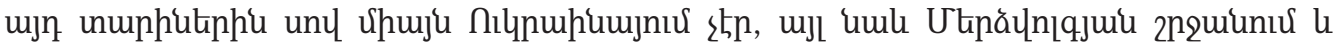

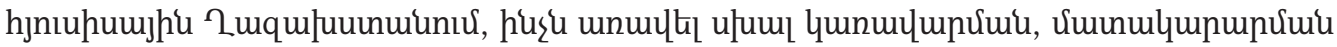

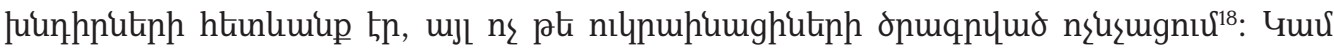

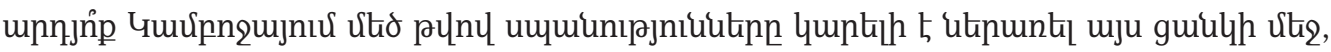

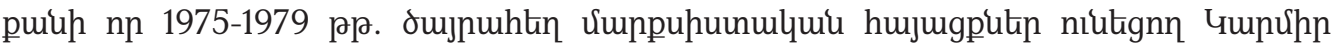

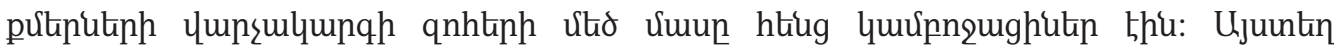

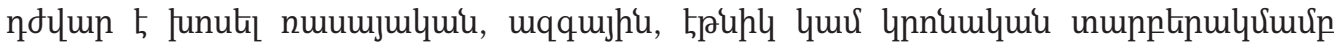

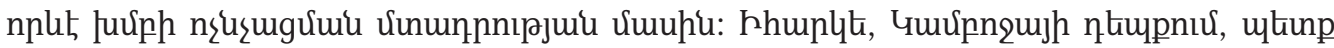

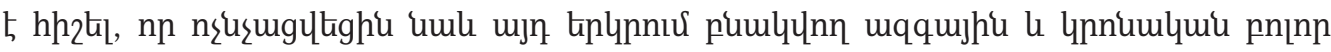

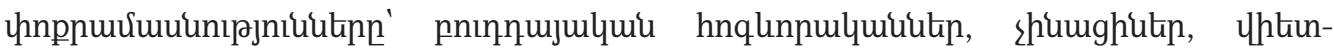

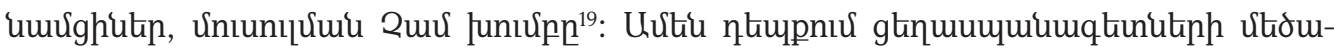

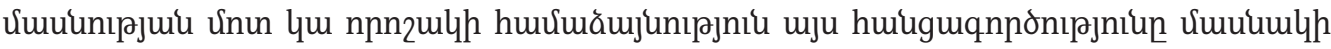

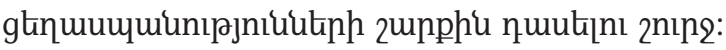

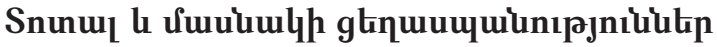

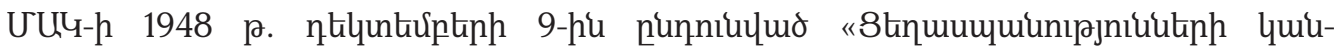

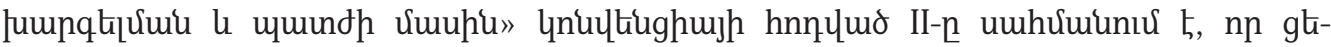

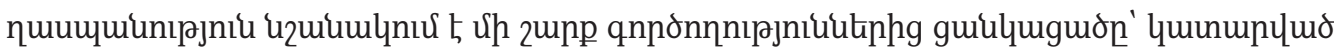

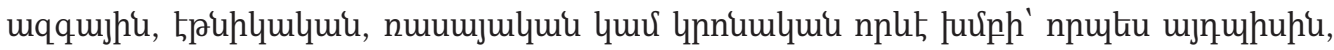

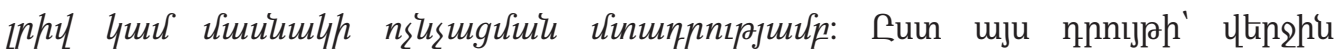

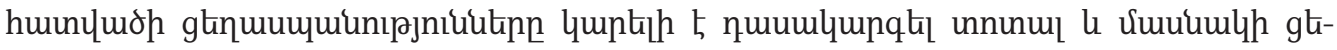
пшuщuiunıjniuuknh:

18 Robert Conquest, The Harvest of Sorrow: Soviet Collectivization and the Terror-Famine (New York: Oxford University Press, 1986); Robert W. Davies, Stephen G. Wheatcroft, The Years of Hunger: Soviet Agriculture, 1931-1933 (Basingstoke: Palgrave Macmillan, 2004); Yaroslav Bilinsky, "Was the Ukrainian Famine of 1932-1933 Genocide?" Journal of Genocide Research 1, no. 2, (1999): 147-156; Norman Naimark, Stalin's Genocides (Princeton: Princeton University Press, 2010); Timothy Snyder, Bloodlands: Europe Between Hitler and Stalin (New York: Basic Books, 2010); Anne Applebaum, Red Famine: Stalin's War on Ukraine (New York: Anchor, 2018).

19 Alexander Laban Hinton, Why Did they Kill?: Cambodia in the Shadow of Genocide (Berkeley, Los Angeles: University of California Press, 2004); Ben Kiernan, The Pol Pot Regime: Race, Power and Genocide in Cambodia under the Khmer Rouge, 1975-1979 (New Haven: Yale University Press, 2002). 


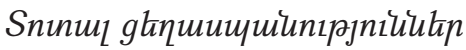

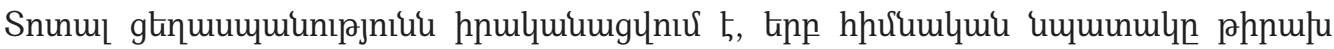

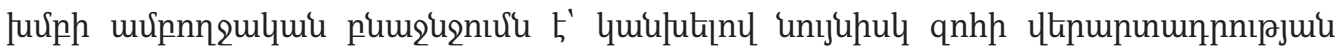

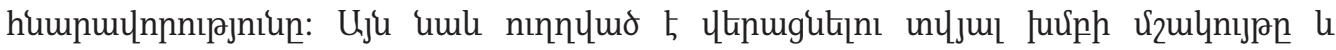

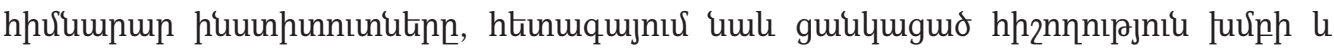

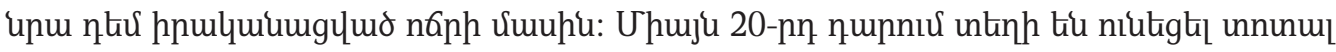

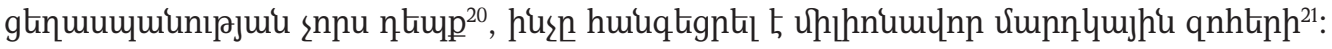

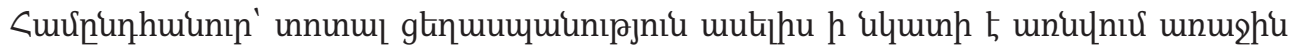

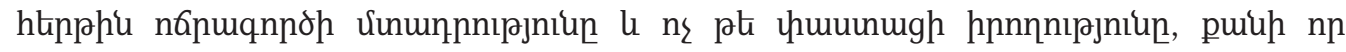

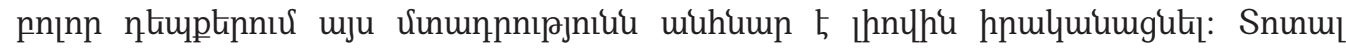

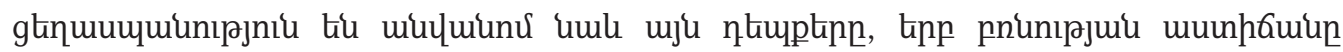

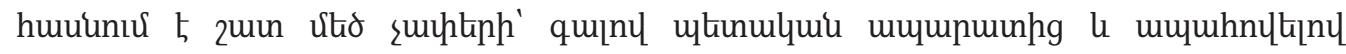

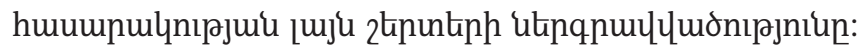

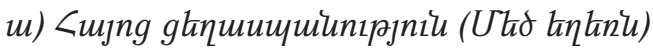

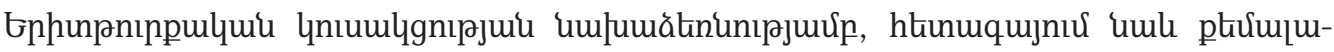

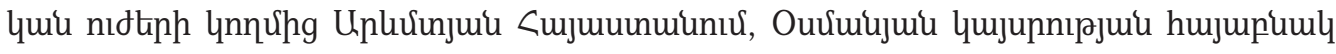

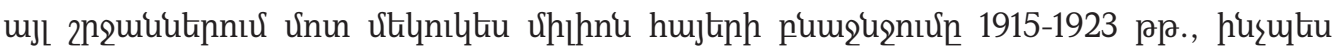

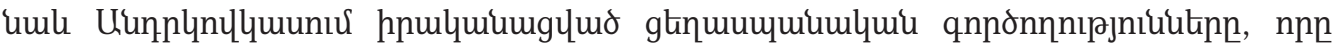

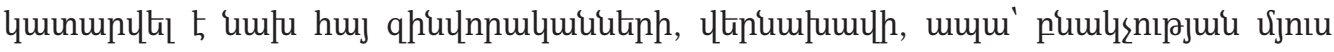

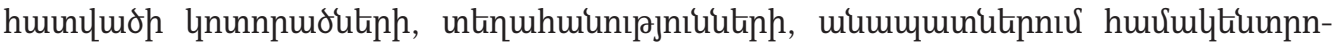

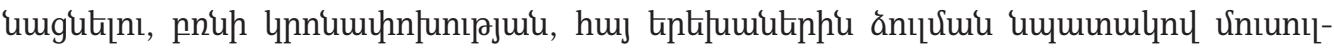

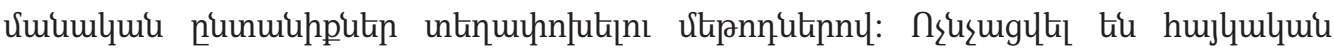

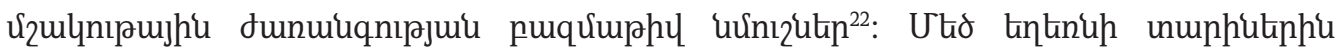

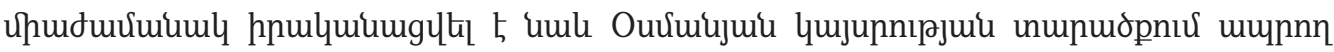

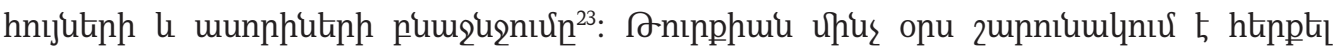

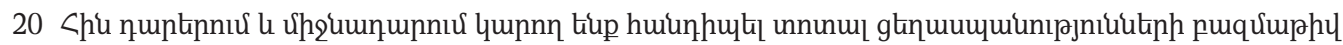

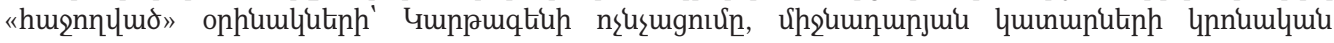

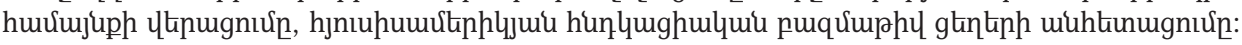

21 Christian P. Scherrer, "Towards a Theory of Modern Genocide. Comparative Genocide Research: Definitions, Criteria, Typologies, Cases, Key elements, Patterns and Voids," Journal of Genocide Research 1, no. 1 (1999): 13-23.

22 A Question of Genocide: Armenians and Turks at the End of the Ottoman Empire, ed. by Ronald G. Suny, Fatma M. Göçek, and Norman M. Naimark (New York, NY: Oxford University Press, 2011); Taner Akcam, A Shameful Act: The Armenian Genocide and the Question of Turkish Responsibility (New York: Metropolitan Books, 2006); Donald Bloxham, The Great Game of Genocide. Imperialism, Nationalism, and the Destruction of the Ottoman Armenians (Oxford: Oxford University Press, 2005); Vahakn Dadrian, The History of the Armenian Genocide: Ethnic Conflict from the Balkans to Anatolia to the Caucasus (Providence, Oxford: Berghahn Books, 2005); Raymond Kevorkian, The Armenian Genocide: A Complete History (London, New York: I.B. Tauris, 2011); Uğur Ümit Üngör, The Making of Modern Turkey: Nation and State in Eastern Anatolia, 1913-1950 (Oxford: Oxford University Press, 2011).

23 Genocide in the Ottoman Empire: Armenians, Assyrians, and Greeks, 1913-1923, ed. George Shirinian (New York, Oxford: Berghahn Books, 2017). 


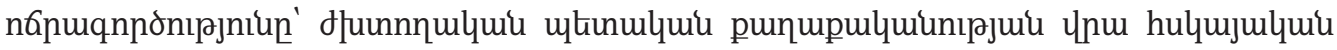
qnưupitip dutuukinu ${ }^{24}$ :

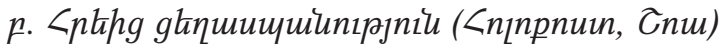

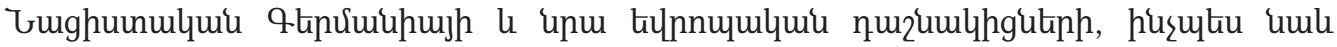

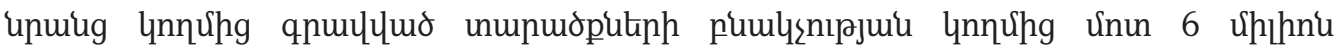

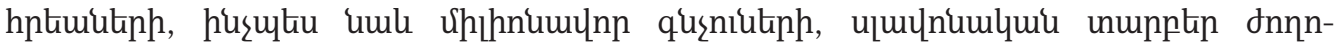

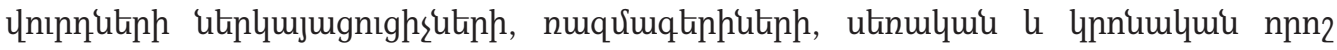

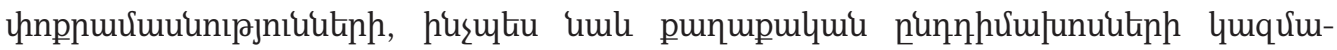

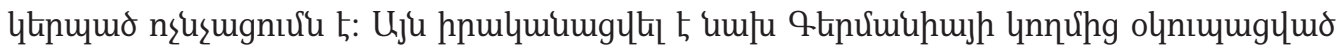

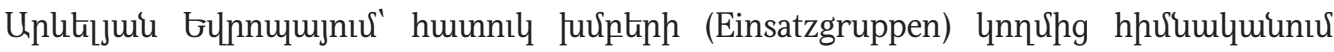

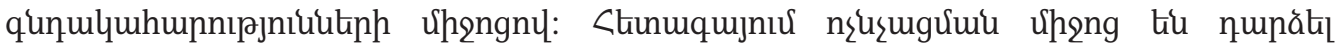

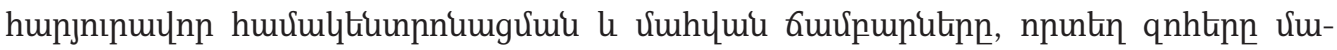

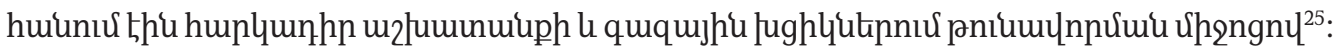

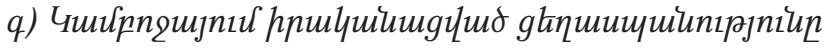

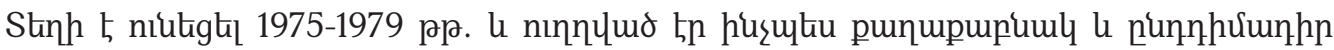

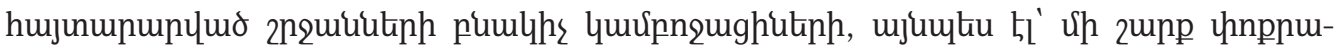

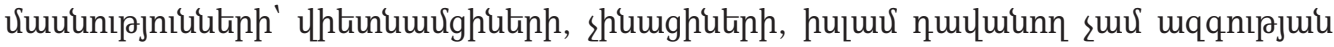

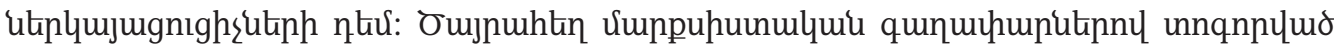

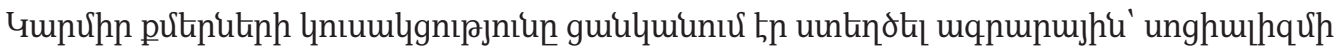

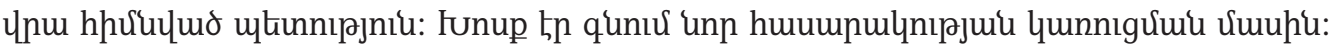

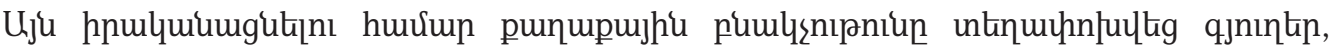

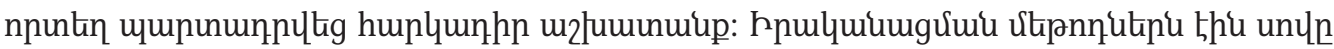

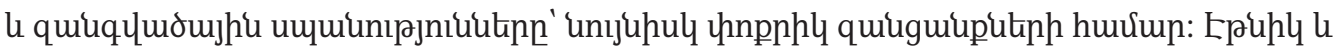

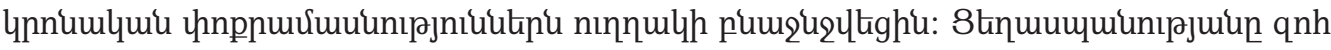
quumg 1,5-2 u्u Uumn ${ }^{26}$ :

24 Fatma M. Göçek, Denial of Violence: Ottoman Past, Turkish Present and Collective Violence against the Armenians, 1789-2009 (Oxford: Oxford University Press, 2015); Doğan Gürpinar, "The Manufacturing of Denial: The Making of the Turkish 'Official Thesis' on the Armenian Genocide between 1974 and 1990," Journal of Balkan and Near Eastern Studies 18, no. 3 (2016): 217-240; Richard G. Hovannisian, "Denial of the Armenian Genocide 100 Years Later: The New Practitioners and their Trade," Genocide Studies International 9, no. 2 (2015): 228-247; Dikran Kaligian, "Anatomy of Denial: Manipulating Sources and Manufacturing a Rebellion," Genocide Studies International 8, no. 2 (2014): 208-223.

25 Raul Hilberg, The Destruction of the European Jews (New Haven: Yale University Press, 2003); Donald Bloxham, The Final Solution: A Genocide (Oxford: Oxford University Press, 2009); Ian Kershaw, The Nazi Dictatorship: Problems and Perspectives of Interpretation (London: Arnold, 2000); Omer Bartov, Germany's War and the Holocaust: Disputed Histories (Ithaca, NY: Cornell University Press, 2003).

26 Elizabeth Becker, When the War Was Over: Cambodia and the Khmer Rouge Revolution (New York: Public Affairs, 1998); Ben Kiernan, The Pol Pot Regime: Race, Power and Genocide in Cambodia under the Khmer Rouge (New Haven, CT: Yale University Press, 2008). 


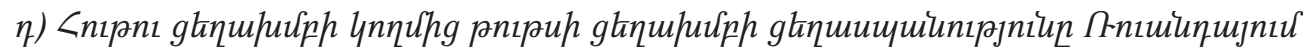

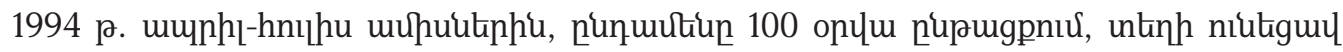

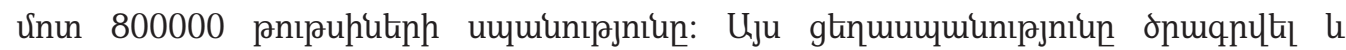

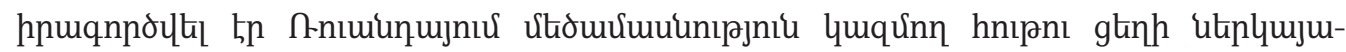

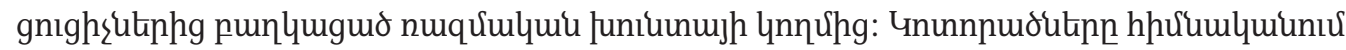

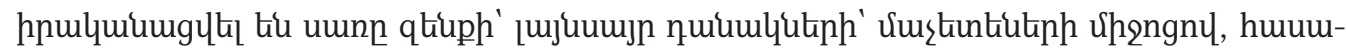

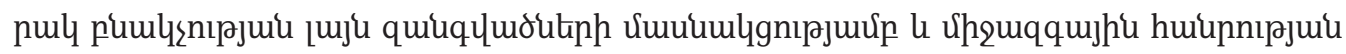

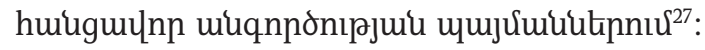

\section{Uwuiuly gtinuuuminnpjnilutip}

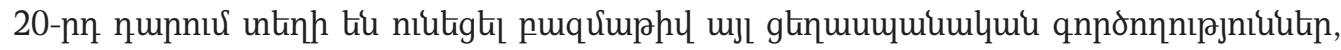

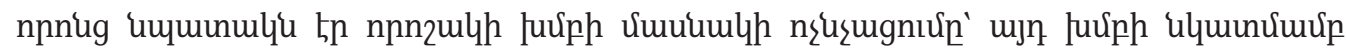

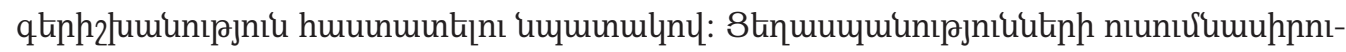

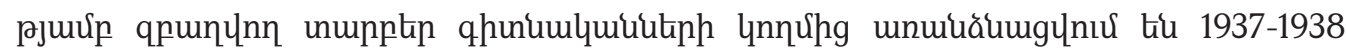

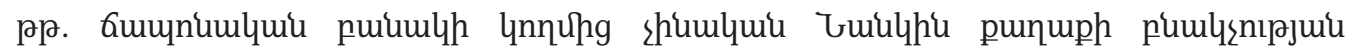

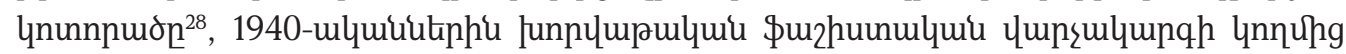

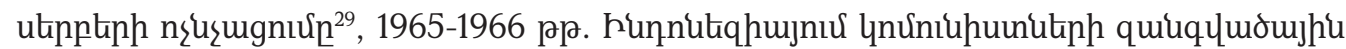

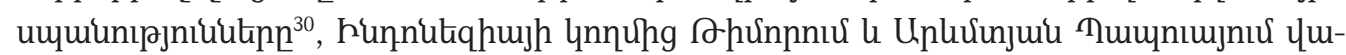

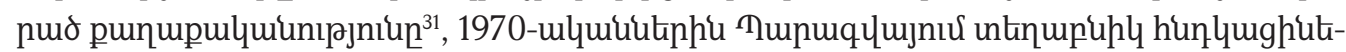

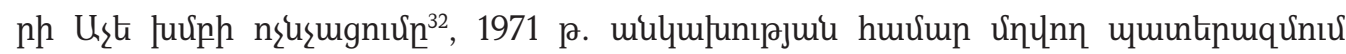

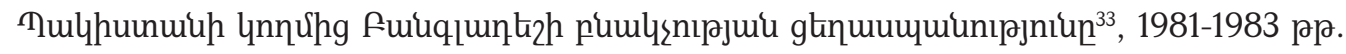

27 Scott Straus, The Order of Genocide: Race, Power, and War in Rwanda (Ithaca, NY: Cornell University Press, 2006); Mahmood Mamdani, When Victims Become Killers: Colonialism, Nativism, and the Genocide in Rwanda (Princeton, NJ: Princeton University Press, 2001); Linda Melvern, Conspiracy to Murder: The Rwanda Genocide and the International Community (London: Verso, 2004); Jean Hatzfeld, Machete Season: The Killers in Rwanda Speak, trans. Linda Coverdale (New York: Farrar, Straus \& Giroux, 2005); Lee Ann Fujii, Killing Neighbors: Webs of Violence in Rwanda (Ithaca, NY: Cornell University Press, 2009).

28 Iris Chang, The Rape of Nanking (New York: Penguin, 1998).

29 Stevan K. Pavlowitch, Hitler's New Disorder: The Second World War in Yugoslavia (London: Hurst Publishers Ltd., 2008); Rory Yeomans, Visions of Annihilation: The Ustasha Regime and the Cultural Politics of Fascism, 1941-1945 (Pittsburgh: University of Pittsburgh Press, 2012).

30 Robert Cribb, Charles Coppel, "A Genocide that Never Was: Explaining the Myth of anti-Chinese Massacres in Indonesia, 1965-66," Journal of Genocide Research 11, no. 4 (2009): 447-465; The Indonesian Genocide of 1965: Causes, Dynamics and Legacies, eds. Katharine McGregor, Jess Melvin, Annie Pohlman (Palgrave Macmillan, 2018); Geoffrey B. Robinson, The Killing Season: A History of the Indonesian Massacres, 1965-66 (Princeton: Princeton University Press, 2018); John Roosa, Buried Histories: The Anticommunist Massacres of 1965-1966 in Indonesia (Madison, Wisconsin: University of Wisconsin Press, 2020).

31 East Timor at the Crossroads: the Forging of a Nation, eds. Peter Carey, Carter Bentley (Honolulu, HI: University of Hawaii Press, 1995); Matthew Jardine, East Timor: Genocide in Paradise (Berkeley, CA: Odonian Press, 1999); John G. Taylor, East Timor: The Price of Freedom (London: Zed Books, 2000).

32 Richard Arens, Genocide in Paraguay (Philadelphia, PA: Temple University Press, 1976).

33 Rounaq Jahan, "Genocide in Bangladesh," in Century of Genocide: Eyewitness Accounts and Critical 


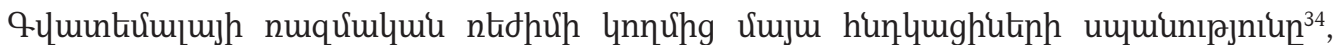

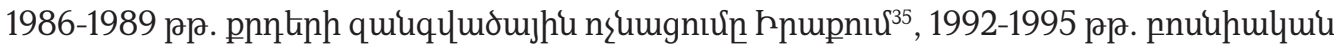

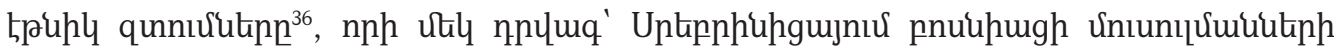

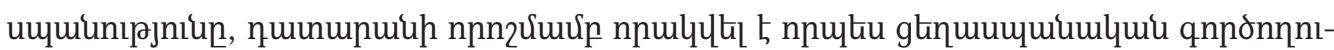

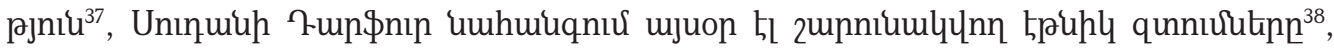

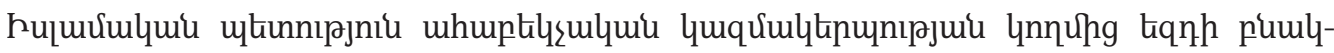

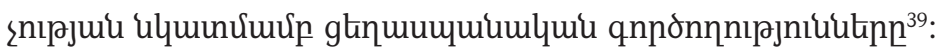

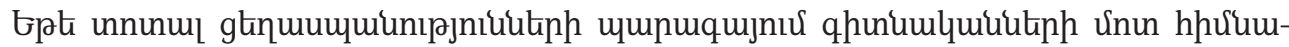

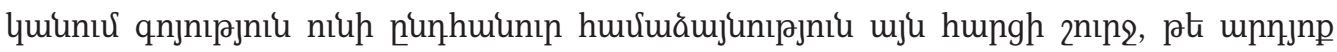

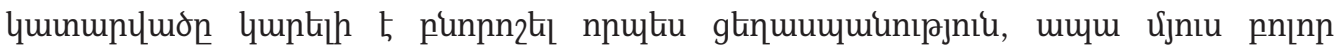

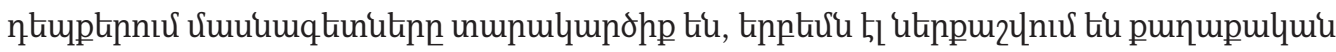

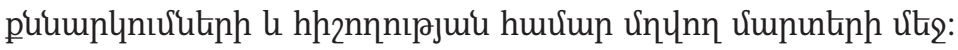

\section{Ull quuulqupqniútitp}

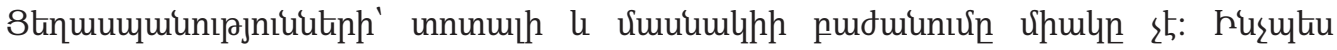

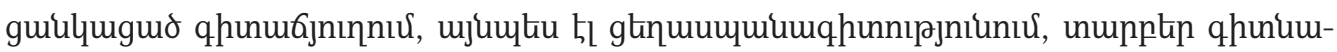

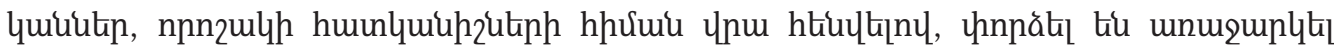

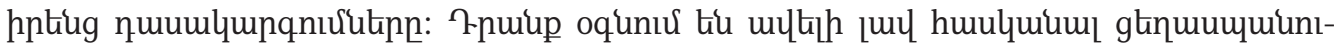

Views, eds. Samuel Totten et al. (New York: Garland Publishing, 1997); Richard Sisson, Leo Rose, War and Secession: Pakistan, India, and the Creation of Bangladesh (Berkeley, CA: University of California Press, 1990); Wardatul Akman, "Atrocities against Humanity during the Liberation War in Bangladesh: a Case of Genocide," Journal of Genocide Research 4, no. 4 (2002): 543-559.

34 Daniel Wilkinson, Silence on the Mountain: Stories of Terror, Betrayal, and Forgetting in Guatemala (Boston, MA: Houghton Mifflin Company, 2002); Roderick Leslie Brett, The Origins and Dynamics of Genocide: Political Violence in Guatemala (London: Palgrave Macmillan, 2016); Robert Carmack, Harvest of Violence: The Maya Indians and the Guatemalan Crisis (Norman, Oklahoma: University of Oklahoma Press, 1988).

35 George Black, Genocide in Iraq: the Anfal Campaign against the Kurds (Human Rights Watch, 1993).

36 Norman Cigar, Genocide in Bosnia: the Policy of "Ethnic Cleansing" (College Station, TX: Texas A\&M University Press, 1995); Ivana Macek, Sarajevo Under Siege: Anthropology in Wartime (Philadelphia, PA: University of Pennsylvania Press, 2009); Ed Vulliamy, Seasons in Hell: Understanding Bosnia's War (New York: St. Martin's Press, 1994); Paul R. Bartrop, Bosnian Genocide: The Essential Reference Guide (Greenwood Press, 2016).

37 https://news.un.org/en/story/2007/02/210142-un-world-court-acquits-serbia-genocide-bosnia-finds-it-

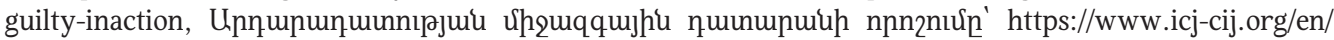
case/91/judgments, nhunltㅣ 5 25.09.2021:

38 Martin W. Daly, Darfur's Sorrow: a History of Destruction and Genocide (Cambridge: Cambridge University Press, 2007); John Hagan, Wenona Rymond-Richmond, Darfur and the Crime of Genocide (Cambridge: Cambridge University Press, 2009).

39 Beth Van Schaack, "The Iraq Investigative Team and Prospects for Justice for the Yazidi Genocide," Journal of International Criminal Justice 16 (2018): 113-139; Pieter Nanninga, "Religion and International Crimes: the Case of the Islamic State" in Perpetrators of International Crimes: Theories, Methods, and Evidence, eds. Alette Smeulers, Maartje Weerdesteijn, Barbora Hola (Oxford: Oxford University Press, 2019). 


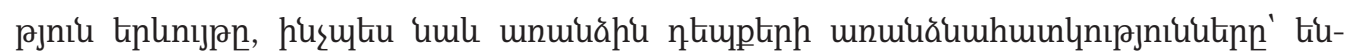

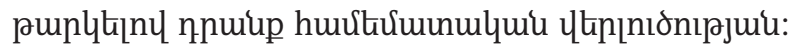

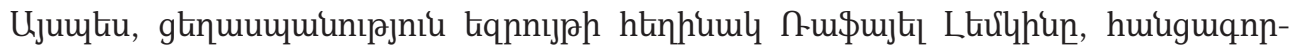

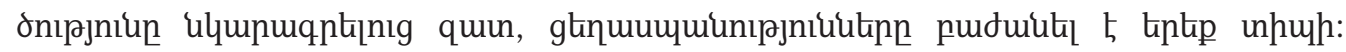

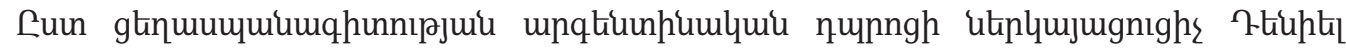

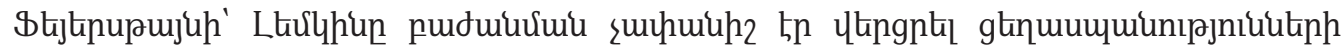

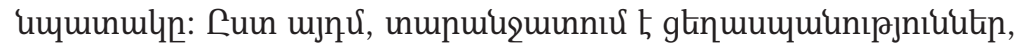

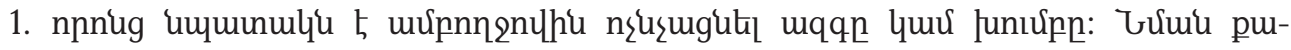

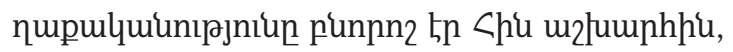

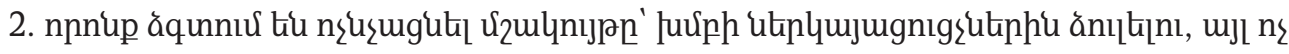

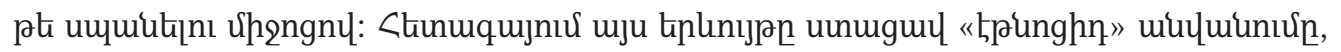

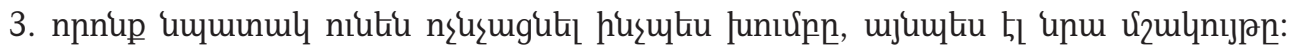

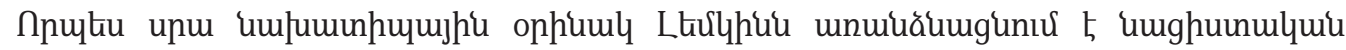

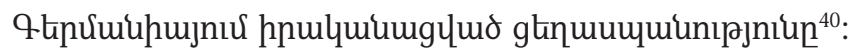

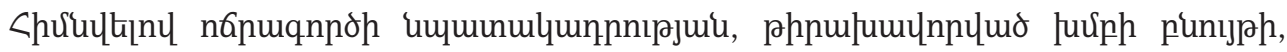

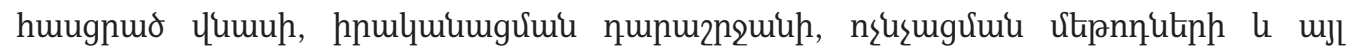

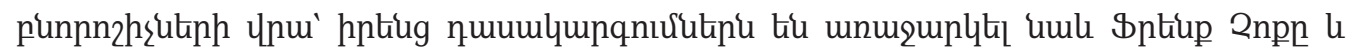

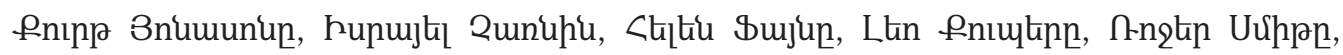

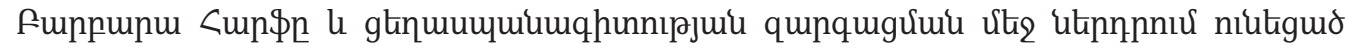
puquimphl ujl hiunuqnunnqukn ${ }^{41}$ :

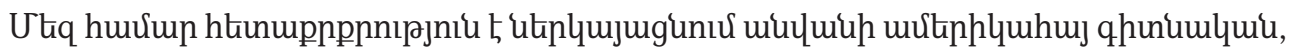

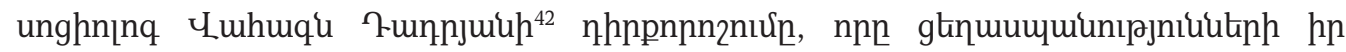

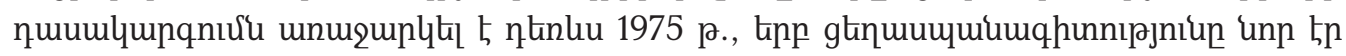

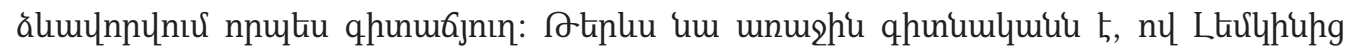
htưnn ưưư ùnnă

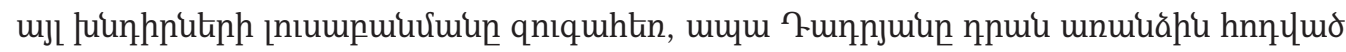

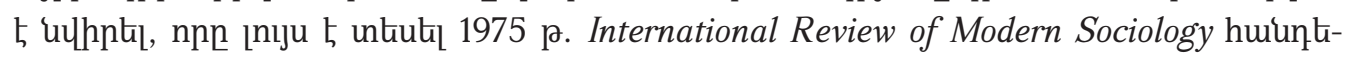
univis:

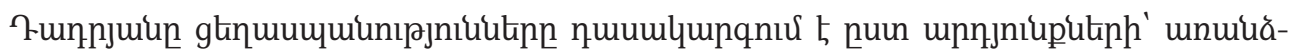
umgutinnl.

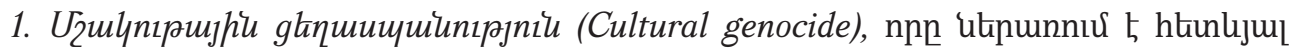

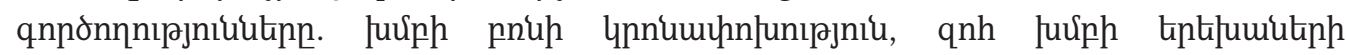

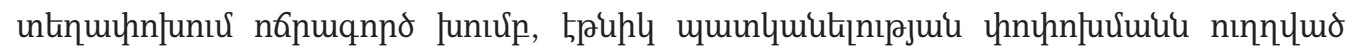

40 Daniel Feierstein, Genocide as Social Practice: Reorganizing Society under the Nazis and Argentina's Military Juntas (New Brunswick, New Jersey: Rutgers University Press, 2014), 40.

41 fnınnh ưuuhu untíu unıju untnnıu, 39-48:

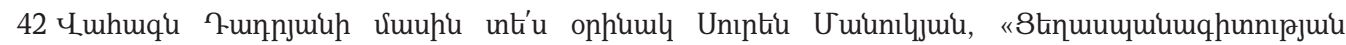

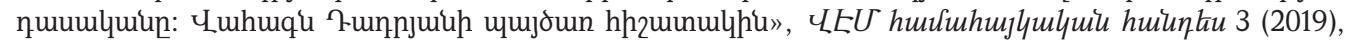
178-192:

43 Vahakn Dadrian, “A Typology of Genocide," International Review of Modern Sociology 5, no. 2 (1975): 201-212. 


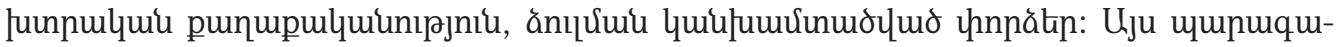

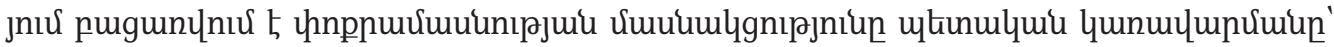

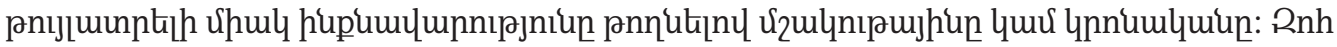

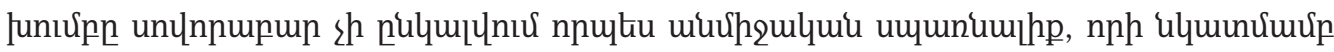

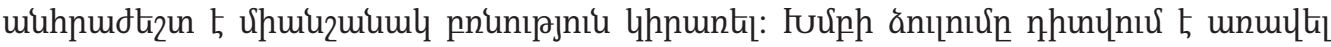

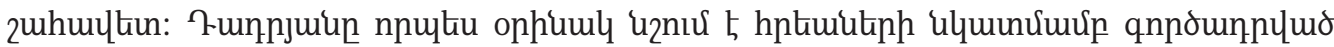

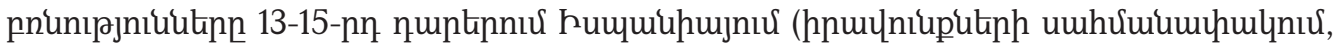

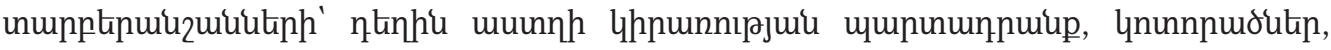

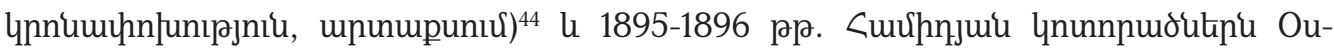

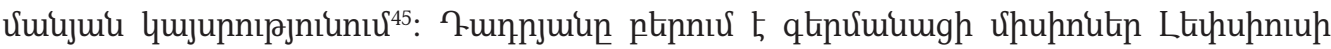

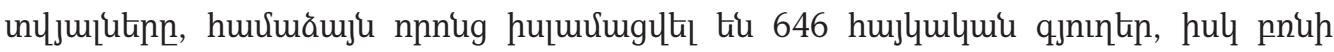

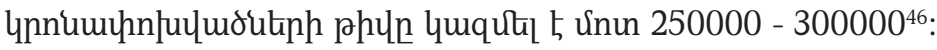

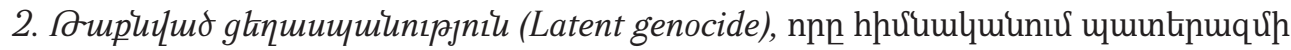

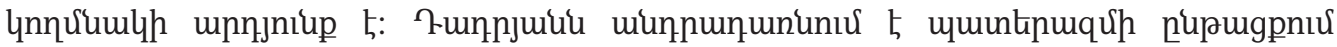

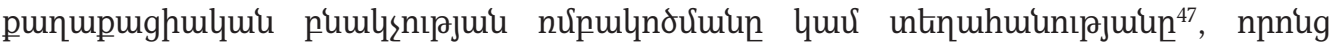

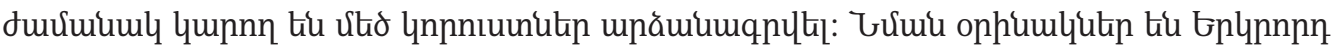

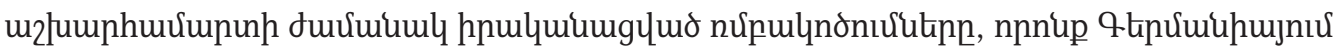

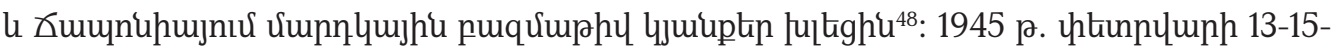

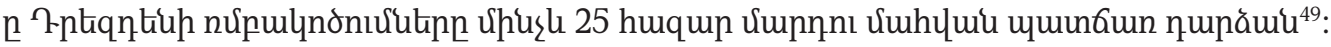

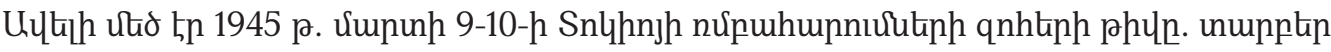

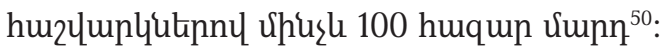

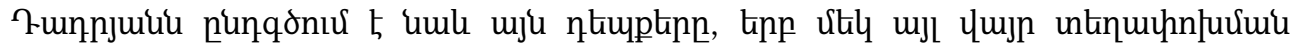

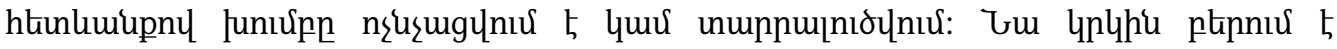

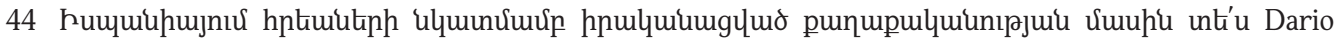
Fernandez-Morera, The Myth of the Andalusian Paradise: Muslims, Christians, and Jews under Islamic Rule in Medieval Spain (Wilmington: Intercollegiate Studies Institute, 2016); Norman Roth, Conversos, Inquisition, and the Expulsion of the Jews from Spain (Madison, Wisconsin: University of Wisconsin Press, 2002); Norman Roth, The Bible and Jews in Medieval Spain (Abingdon-on-Thames: Routledge, 2021):

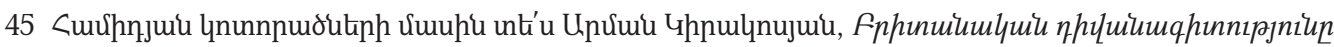

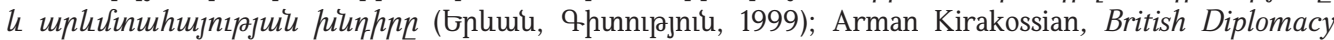
and the Armenian Question (Princeton and London: Gomidas Institute, 2003); Arman Kirakossian, The Armenian Massacres 1894-1896: British Media Testimony (Armenian Research Center: University of Michigan Dearborn Press, 2008).

46 Dadrian, “A Typology of Genocide," 205.

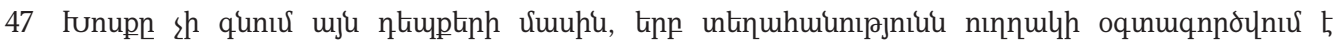

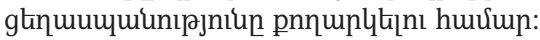

48 Dadrian, “A Typology of Genocide," 206.

49 Sinclair McKay, The Fire and the Darkness: The Bombing of Dresden, 1945 (New York, NY: St. Martin's Press, 2020); Firestorm: The Bombing of Dresden, eds. Paul Addison, Jeremy A. Crang (London: Pimlico, 2006).

50 The Firebombing of Dresden and Tokyo: The History and Legacy of the Allies Controversial Bombing Campaigns Near the End of World War II, ed. Charles River (Scotts Valley: CreateSpace Independent Publishing Platform, 2017). 


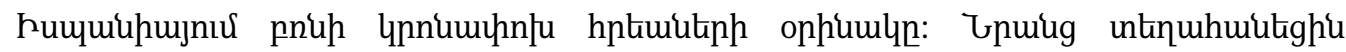

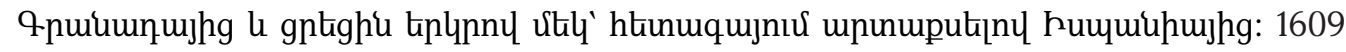

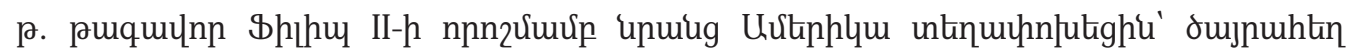

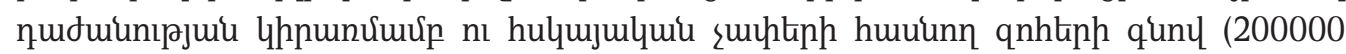

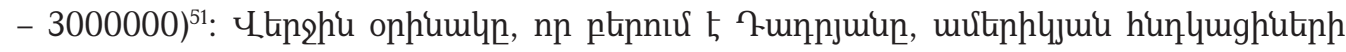

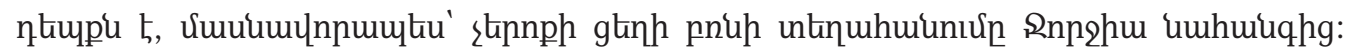

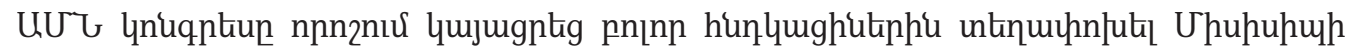

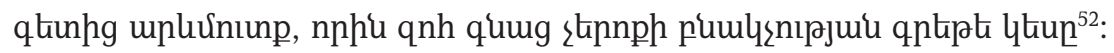

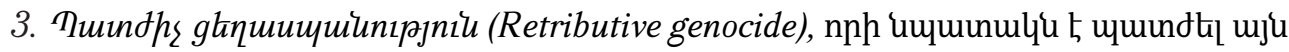

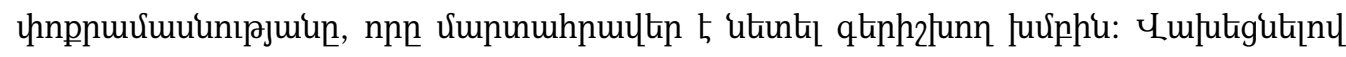

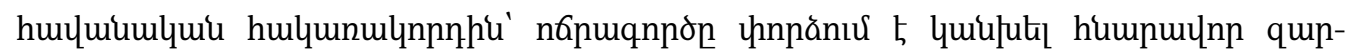

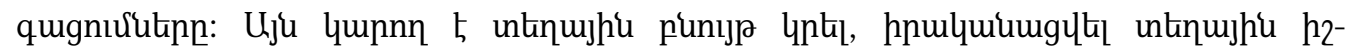

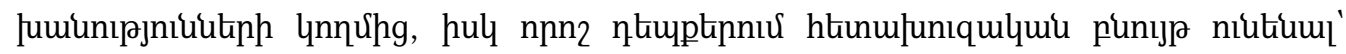

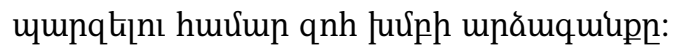

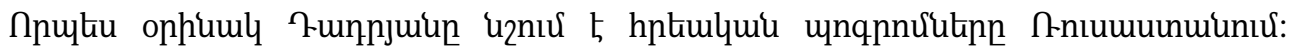

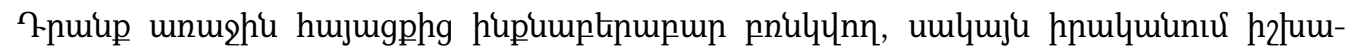

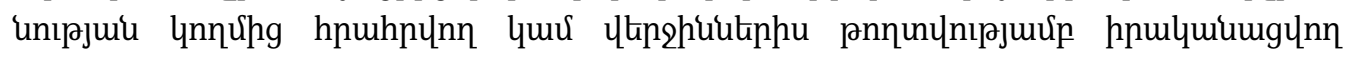

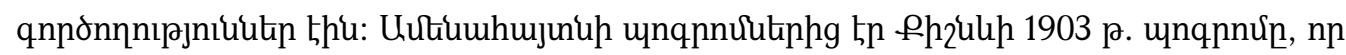

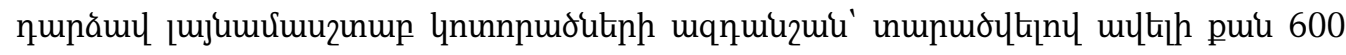

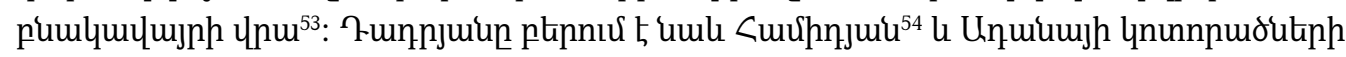
ophumlutinn ${ }^{55}$ :

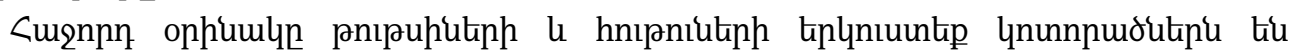

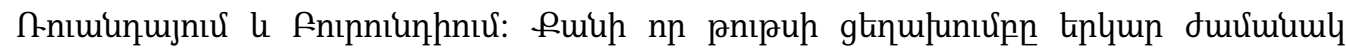

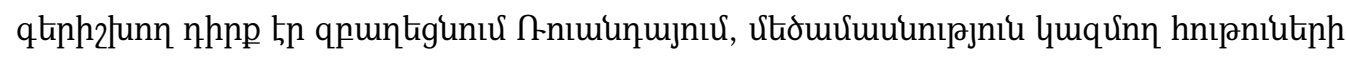

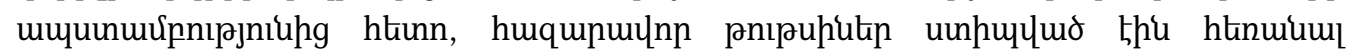

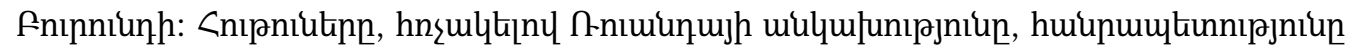

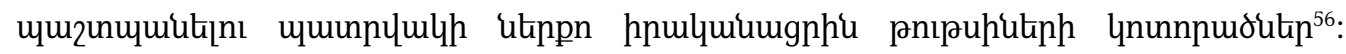

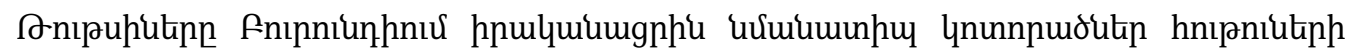
ulumunumurp ${ }^{57}$ :

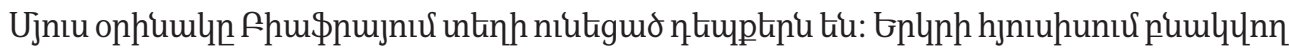

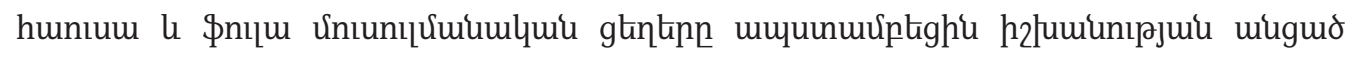

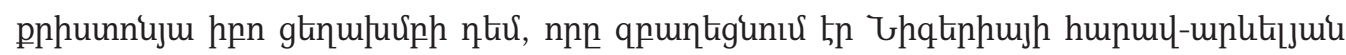

51 Dadrian, "A Typology of Genocide," 206.

52 ঢnıju unknnuर, 207:

53 James W. Parkes, The Jewish Problem in the Modern World (Oxford: Oxford University Press, 1939), 63-74.

54 Dadrian, "A Typology of Genocide," 207.

55 七nıju untinnux:

56 ษnıju unŁnnux, 208:

57 ษnıju unknnux: 


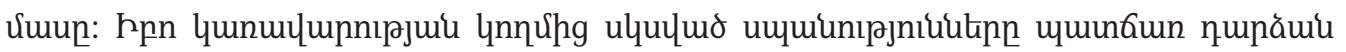

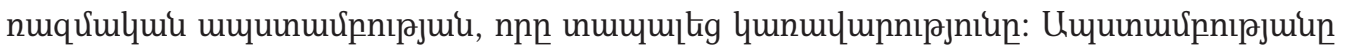

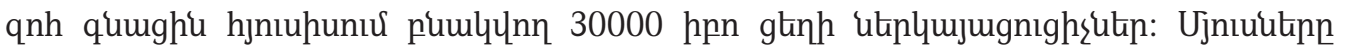

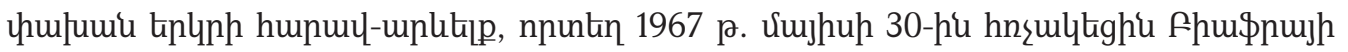

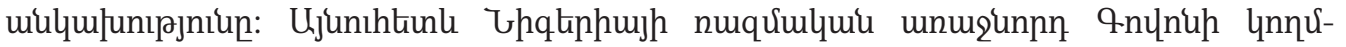

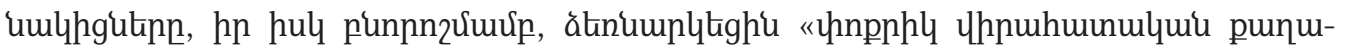

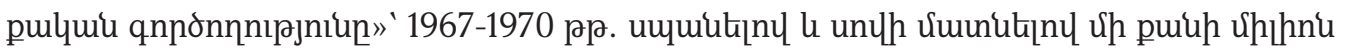
hpn ginnh utphlujugnıghšliph ${ }^{58}$ :

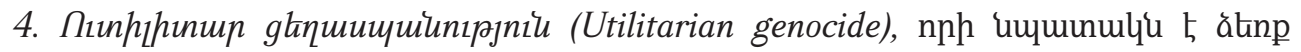

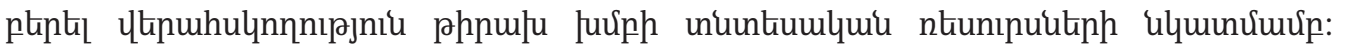

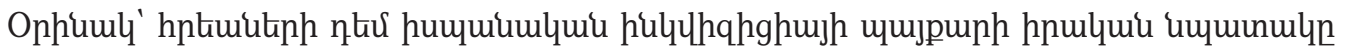

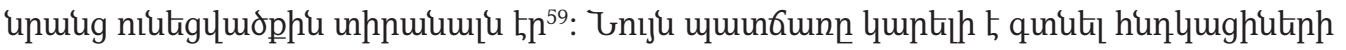

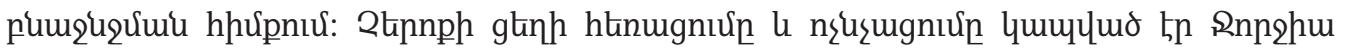

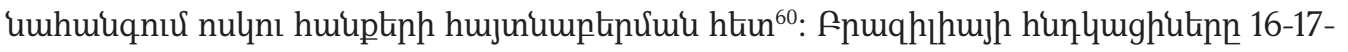

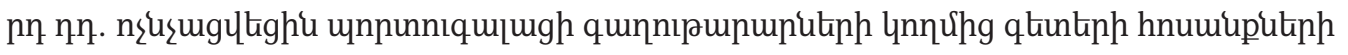

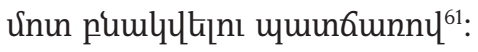

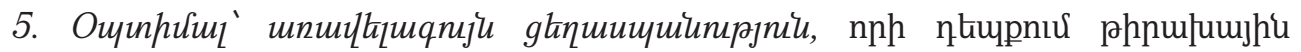

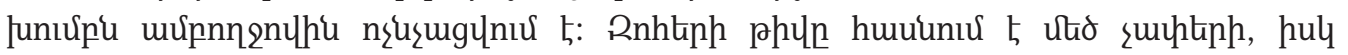

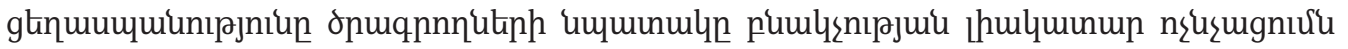

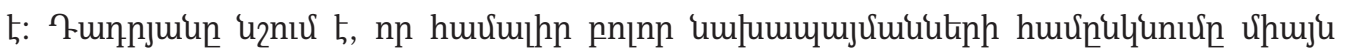

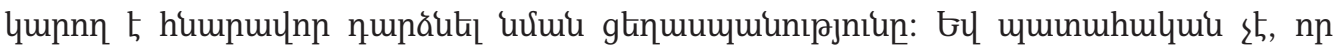

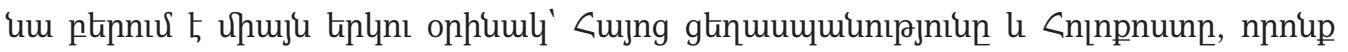

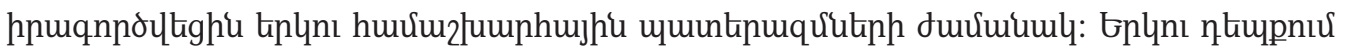

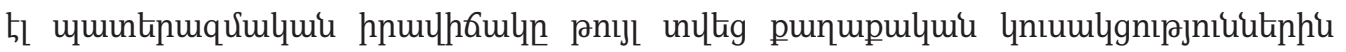

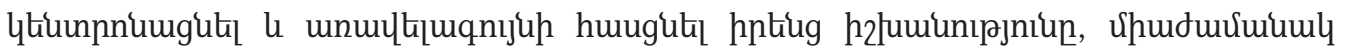

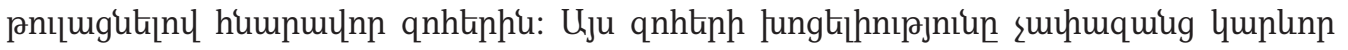

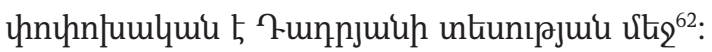

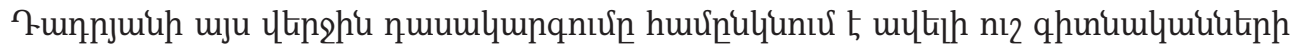

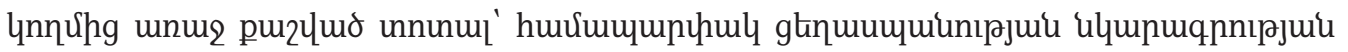

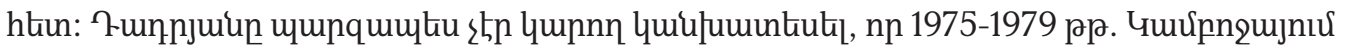

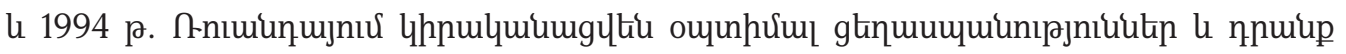
utpuntel guuluniर:

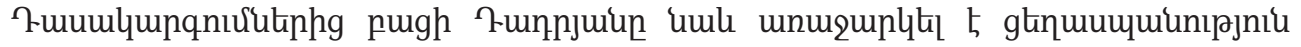

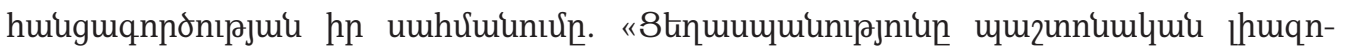

58 Łnıju unknnux:

59 Juan A. Llorente, A Critical History of the Inquisition of Spain (Williamstown: The John Lilburne Co, 1967).

60 Marion L. Starkey, The Cherokee Nation (New York: Alfred A. Knopf, 1946), 282-301.

61 Dadrian, “A Typology of Genocide," 209.

62 Łnıju untฑnư, 210: 


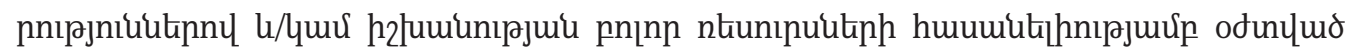

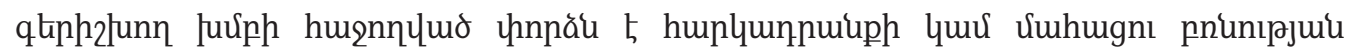

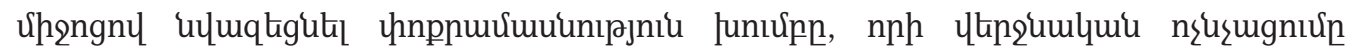

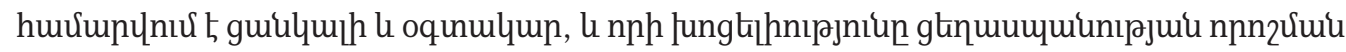

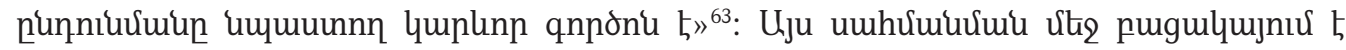

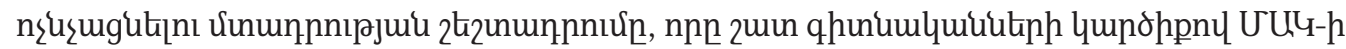

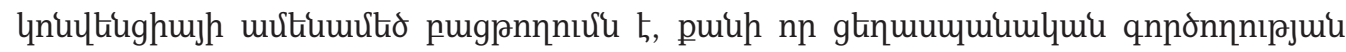

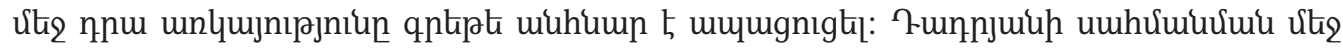

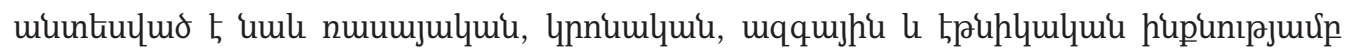

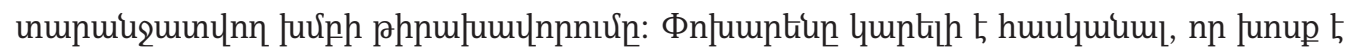

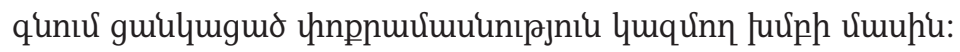

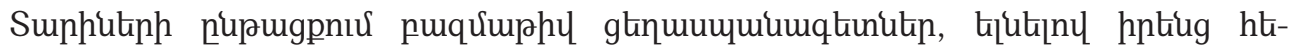

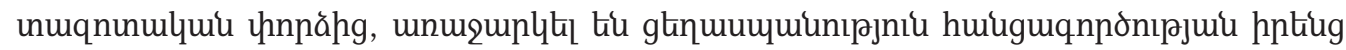

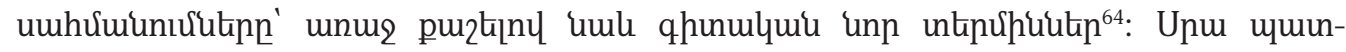

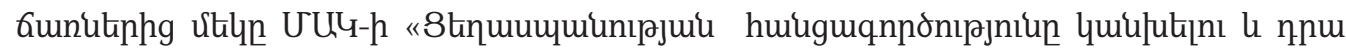

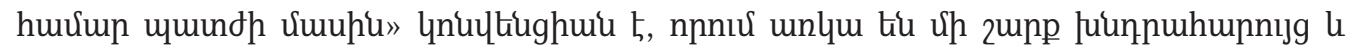

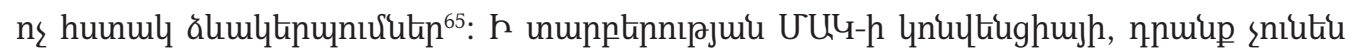

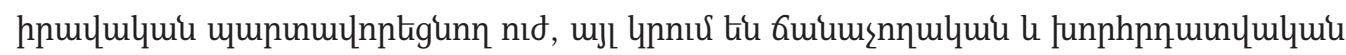
punijp:

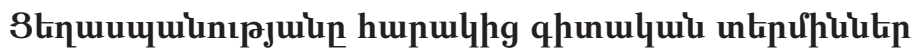

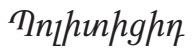

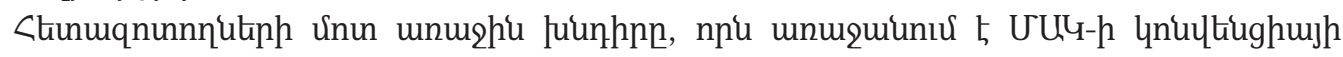

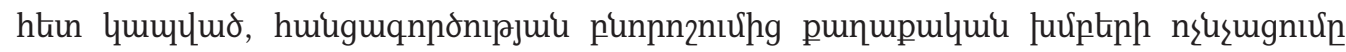

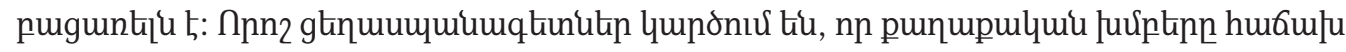

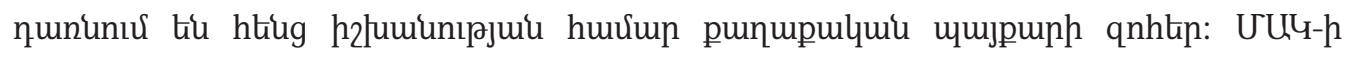

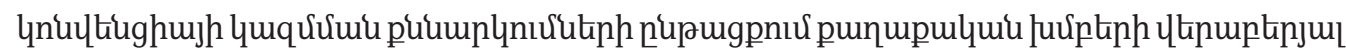

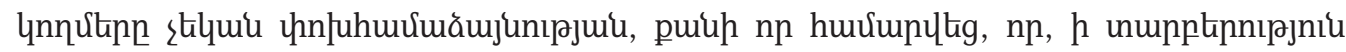

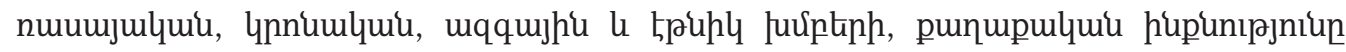

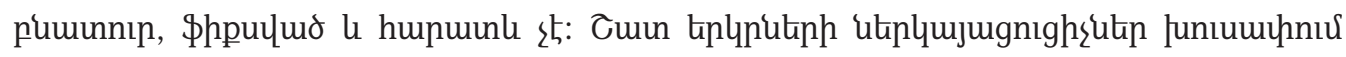

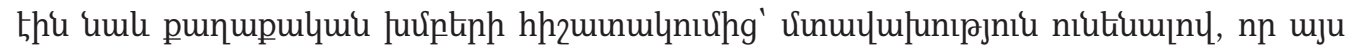

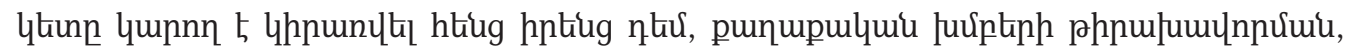

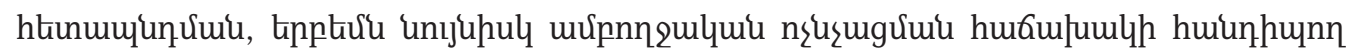

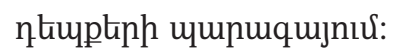

63 Dadrian, “A Typology of Genocide," 204.

64 Uju punnn2nưutiph Uumulu unt'u Adam Jones, Genocide. A Comprehensive Introduction (Abingdon-onThames: Routledge, 2011), 16-20:

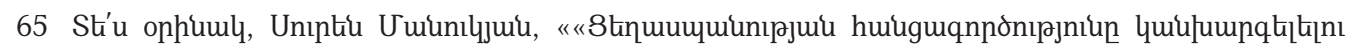

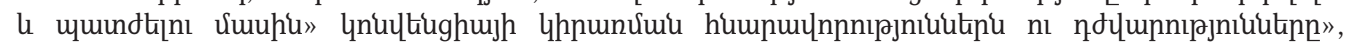

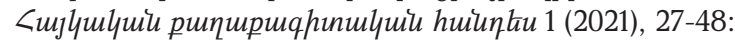




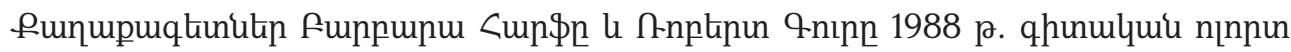

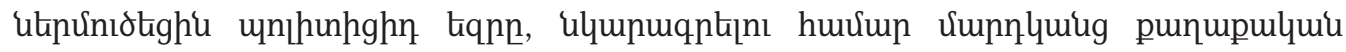

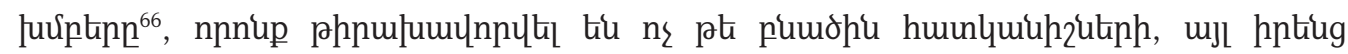

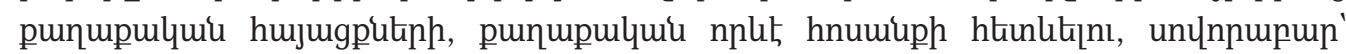

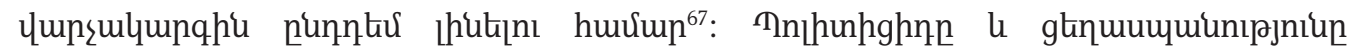

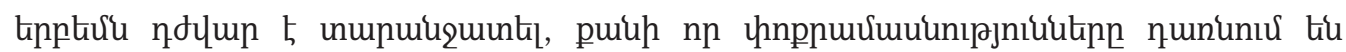

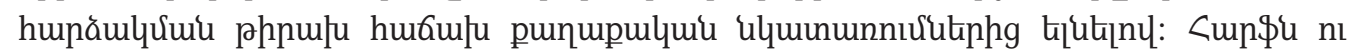

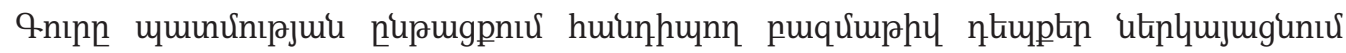

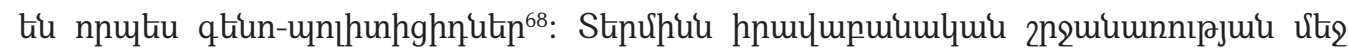

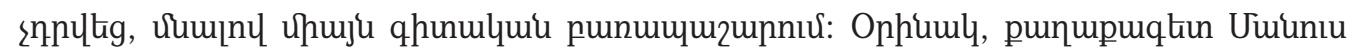

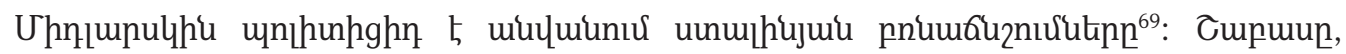

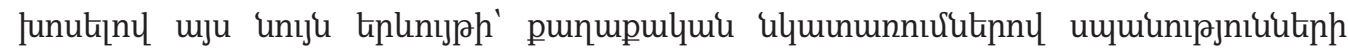
রuuhu, oqunuqnnonı

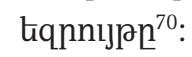

\section{Elhinhghn}

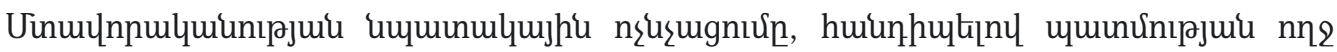

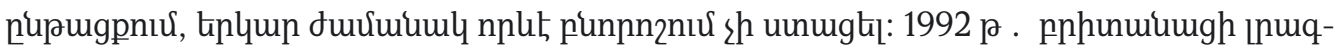

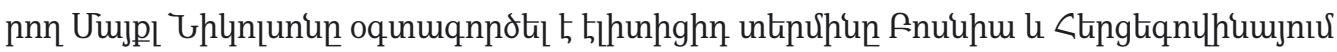

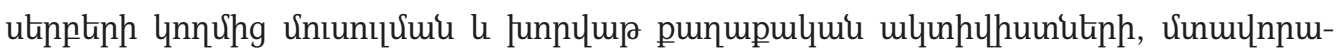

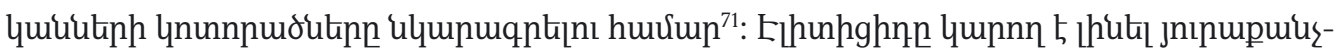

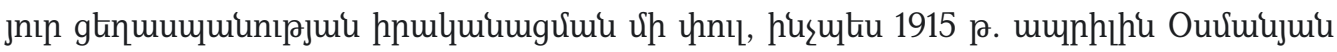

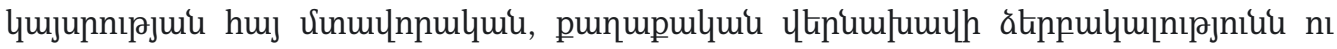

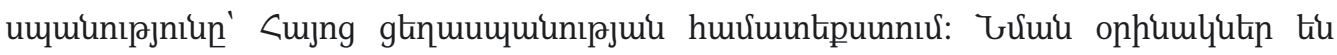

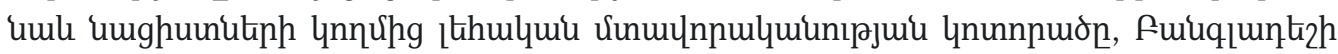

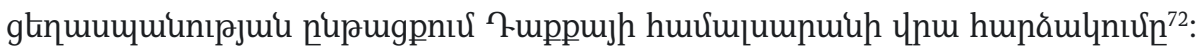

66 Barbara Harff, Ted Gurr, "Toward Empirical Theory of Genocides and Politicides: Identification and Measurement of Cases since 1945," International Studies Quarterly 32, no. 3 (1988): 359-71.

67 Barbara Harff, "Recognizing Genocides and Politicides," in Genocide Watch, ed. Helen Fein (New Haven, CT: Yale University Press, 1992), 27-41.

68 Daniel Feierstein, "Leaving the Parental Home: An Overview of the Current State of Genocide Studies," Genocide Studies and Prevention 6, no.3 (2011): 259.

69 Manus Midlarsky, The Killing Trap: Genocide in the Twentieth Century (New York: Cambridge University Press, 2005), 22, 309-310, 321.

70 Robert Crib, "Political Genocides in Postcolonial Asia," The Oxford Handbook of Genocide Studies, eds. D. Bloxham, D. Moses (New York: Oxford University Press, 2010), 446.

71 Cathie Carmichael, "Genocide and Population Displacement in Post-Communist Eastern Europe," The Oxford Handbook of Genocide Studies, ed. Donald Bloxham, Dirk Moses (New York: Oxford University Press, 2010), 521.

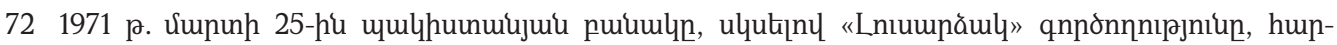

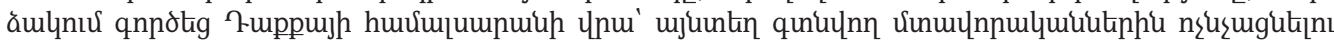

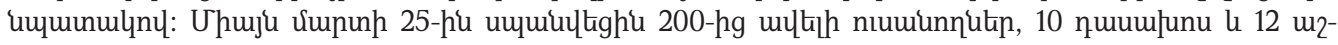




\section{Thiuntinghn}

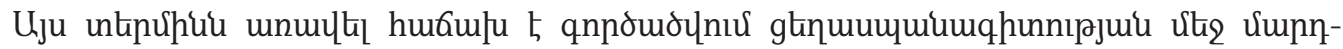

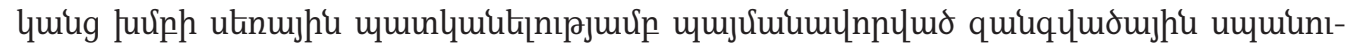

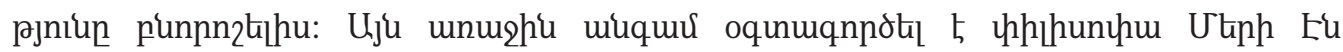

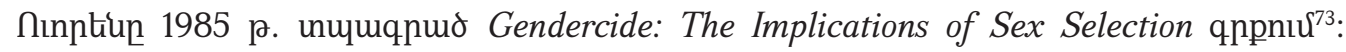

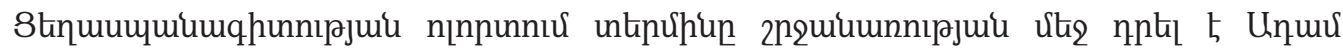

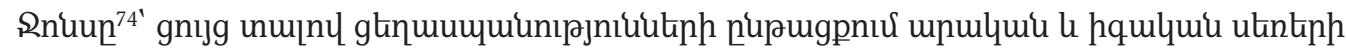

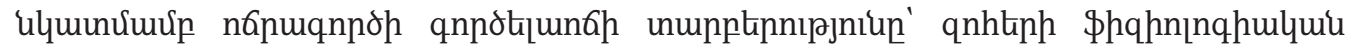

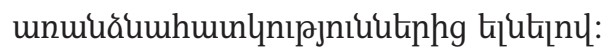

\section{Epunghn}

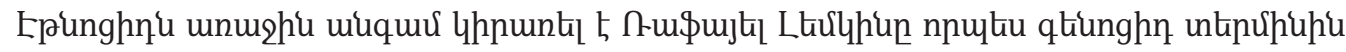

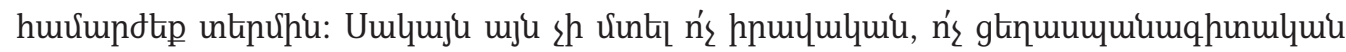

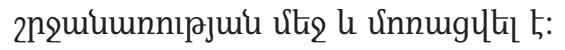

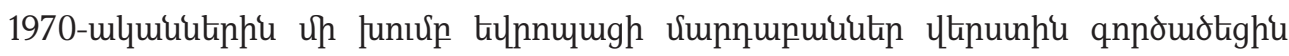

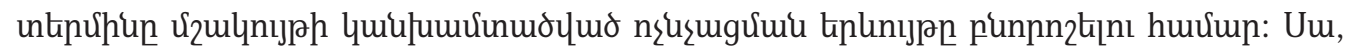

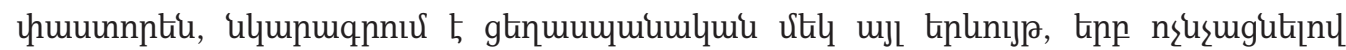

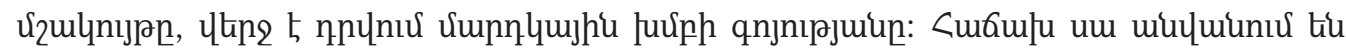

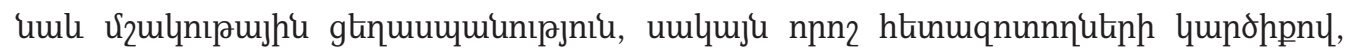

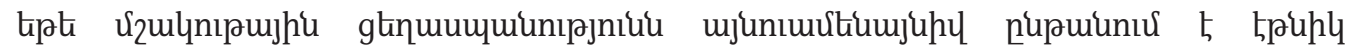

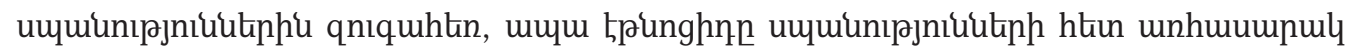

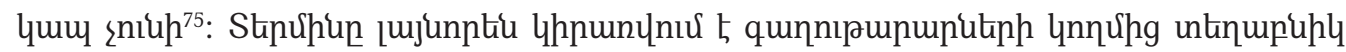

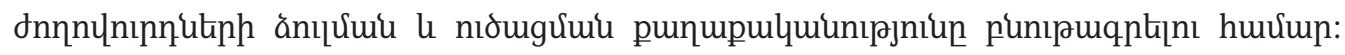

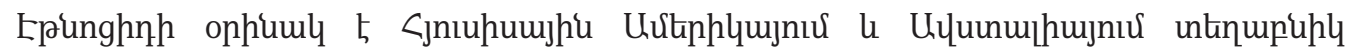

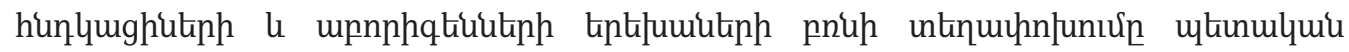

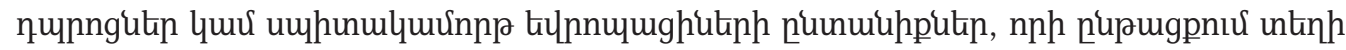

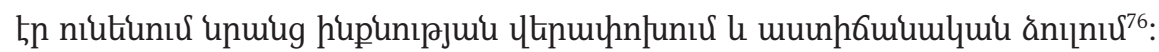

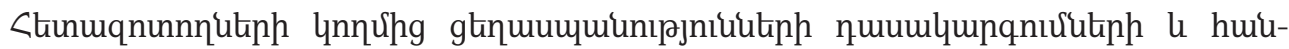

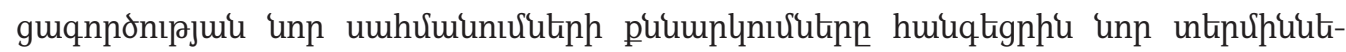

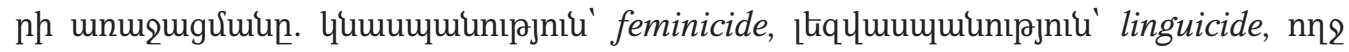

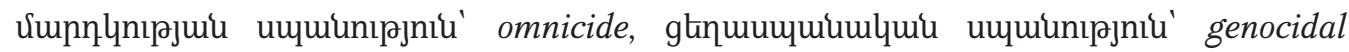

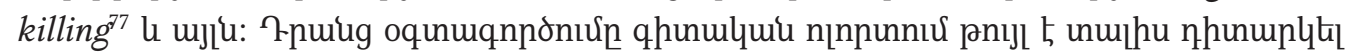

luuunulhhg: Maloy Dutta, "Pak Army killed 200 students, 10 teachers at DU on March 25," The Daily Observer, 25 March 2015, https://www.observerbd.com/2015/03/25/79918.php, nhunlth t 22.11.2021.

73 Mary Ann Warren, Gendercide: The Implications of Sex Selection (Totowa: Rowman \& Allanheld, 1985).

74 Adam Jones, “Gendercide and Genocide," Journal of Genocide Research 2 (2002): 185-187.

75 Barry Sautman, “Cultural Genocide and Tibet," Texas International Law Journal 38 (2003): 173-248.

76 Andrew Woolford, "This Benevolent Experiment": Indigenous Boarding Schools, Genocide and Redress in North America (Nebraska: University of Nebraska Press, 2015).

77 Eric Markusen, Damir Mirkovic, "Understanding Genocidal Killing in the Former Yugoslavia: 


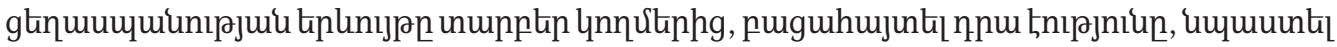

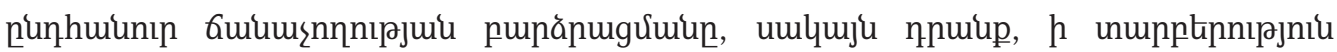

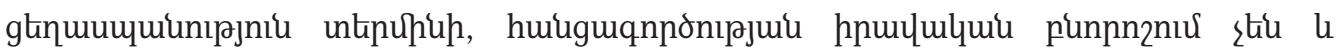

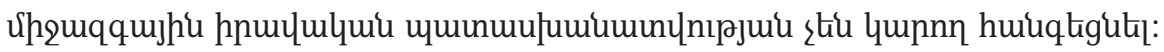

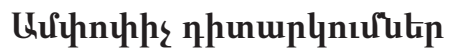

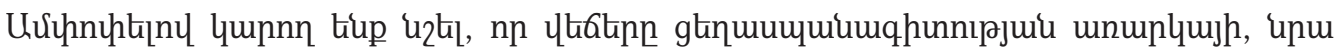

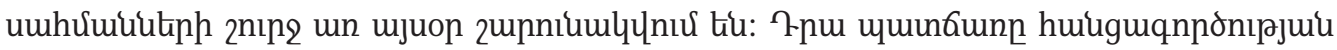

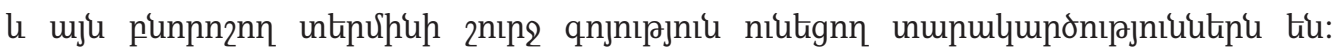

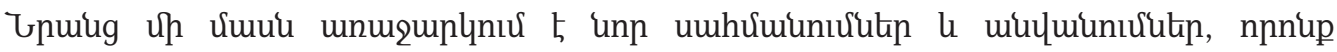

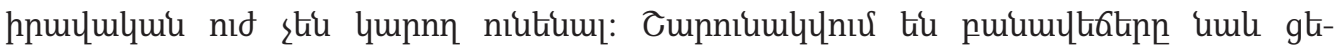

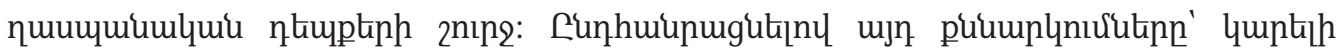

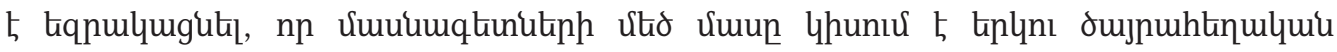

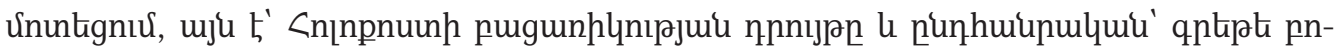

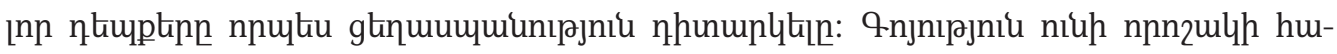

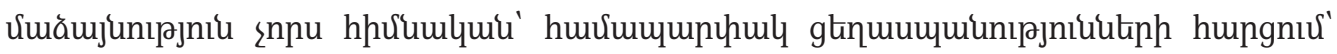

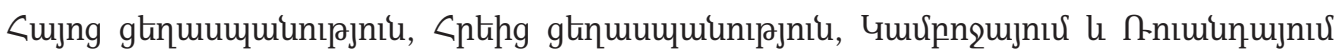

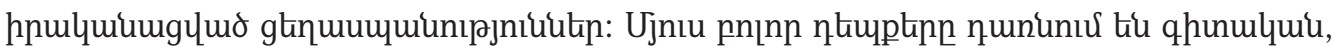

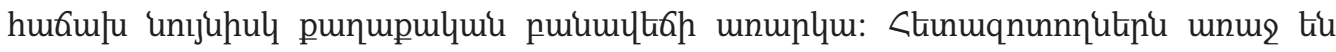

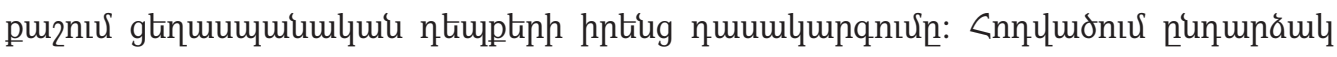

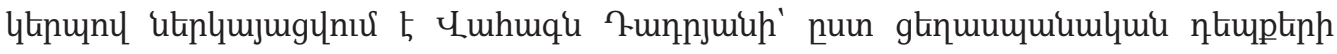

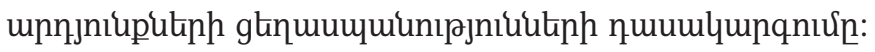

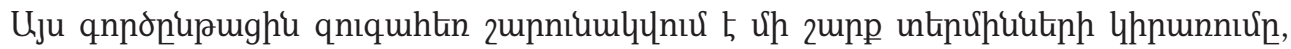

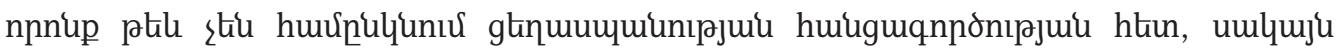

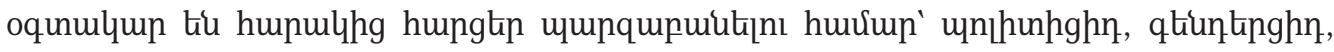
Łlhunhghn:

Preliminary Observations," in Collective Violence, eds. C. Summers, E. Markusen (Lanham: Rowman \& Littlefield, 1999), 37; Jones, Genocide. A Comprehensive Introduction, 26-28. 


\title{
ON THE ACADEMIC CLASSIFICATIONS OF GENOCIDES
}

\author{
Suren A. Manukyan
}

Armenian Genocide Museum-Institute Foundation, Armenia

\begin{abstract}
SUMMARY
Discussion continues over the subject of genocide, the boundaries of the crime, as genocide scholars debate its key concept, the term genocide. Some of them have contributed their own definitions of the phenomenon, which cannot have legal force. Disputes continue over whether the massacres can be considered genocide or not. It can be summed up that most scholars are in the middle ground between the two farthest approaches (if some argue for the uniqueness of the Holocaust, then the other camp offers a broad, almost universal inclusion of mass murder cases under the definition of genocide). There is almost complete consensus on the four major genocides: the Armenian Genocide, the Holocaust, the Cambodian Genocide, and the Rwandan Genocide. But many more other cases are the subject of academic and often political debate.

To clarify this debate, comparative genocide studies and the classification of genocides can be helpful. The classification of Vahakn Dadrian is essential for us. He divided genocidal cases into four groups: Cultural, Latent, Retributive, Utilitarian and Optimal genocide, based on the outcome of the genocide.

In parallel with this process, several terms continue to be used that do not correspond with genocide, but help explain related issues: politicide, gendercide, eliticide. However, we should remember that genocide is a legal term; the others are not.
\end{abstract}

Key words: Genocide, total and partial genocides, Katz-Charny debate, Holocaust, Vahakn Dadrian, politicide, gendercide, eliticide, ethnocide.

\section{К ВОПРОСУ ОБ АКАДЕМИЧЕСКИХ КЛАССИФИКАЦИЯХ ГЕНОЦИДОВ}

Сурен А. Манукян

Фонд “Музей-институт Геночида армян,” Армения

\section{РЕЗЮМЕ}

Дискуссии по поводу определения геноцида, его границ продолжаются до сих пор, поскольку ученые, исследующие геноцид, обсуждают его определение - термин геноцид. Некоторые из них предлагали свои собственные определения этого явления, которые, однако, не могут иметь юридической силы. Продолжаются споры о том, какие массовые убийства можно считать геноцидом, а какие не подходят под это определение. Можно сказать, что большинство ученых находятся между двумя самыми радикальными подходами (если одни отстаивают уникальность 
Холокоста, то другие предлагают широкое, почти универсальное включение всех случаев массовых убийств в определение геноцида). Сушествует почти полный консенсус по четырем основным тотальным геноцидам: геноциду армян, холокосту, геноциду в Камбодже и геноциду в Руанде. Но гораздо больше случаев являются предметом академических и часто политических дебатов.

Для прояснения этой дискуссии, могут быть полезными сравнительные исследования геноцида и классификация геноцидов. Нами выделена классификация известного социолога Ваакна Дадряна. Основываясь на результатах геноцида, он разделил случаи геноцида на четыре группы: культурный, скрытый, карательный, утилитарный и оптимальный геноцид.

Параллельно с этим процессом в научной литературе продолжают использоваться несколько терминов, которые не совпадают с определением геноцида, но помогают объяснить смежные явления: политицид, гендерцид, элитоцид. Однако нужно помнить, что если геноцид - это юридический термин, то другие не имеют юридического обоснования.

Ключевые слова: геноцид, тотальный и частичный геноцид, дискуссия Кац-Чарни, Холокост, Ваагн Дадрян, политицид, гендерцид, элитицид, этноцид.

\section{REFERENCES}

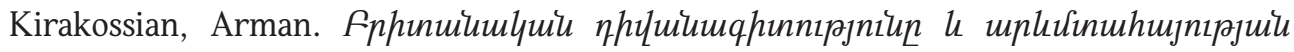
hiunhnn [Armenian Diplomacy and Question of Western Armenians]. Yerevan: Gitut'yun, 1999;

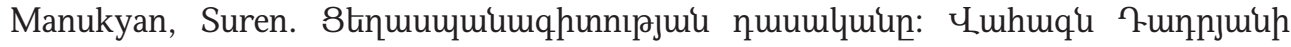
umujoun hhzuunulhi [The Classic of Genocide Study. To the Bright Memory of Vahagn Dadryan]. VEM hamahaykakan handes 3 (2019): 178-192;

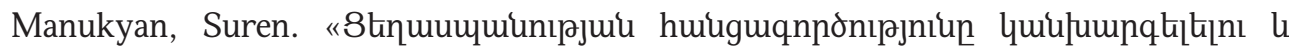

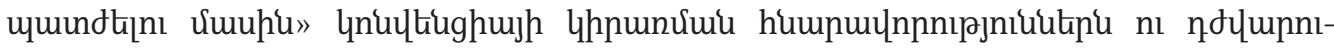
pjnituutinn [Opportunities and Challenges of Implementing the "Convention on the Prevention and Punishment of the Crime of Genocide"]. Haykakan qaghaqagitakan handes 1 (2021): 27-48;

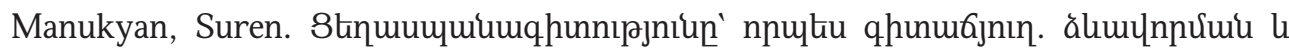
qunqugưuu umununıpjnıin [Genocide Studies as a Scientific Discipline. History of Origin and Development]. VEM hamahaykakan handes 3 (2019): 8-44;

\section{Clinhluwlh uruupis \\ About the Author \\ Об авторе}

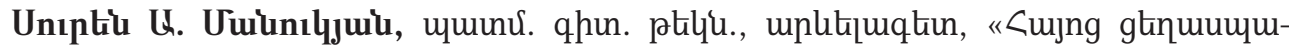

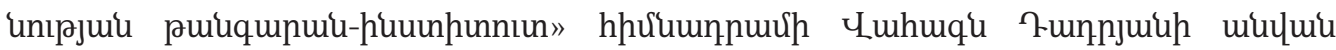

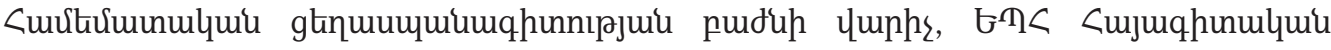




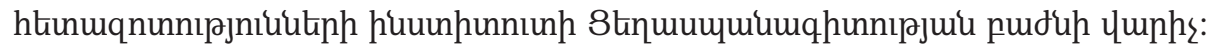

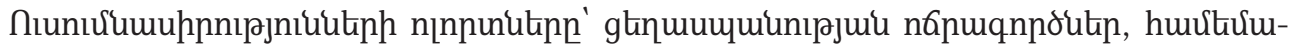

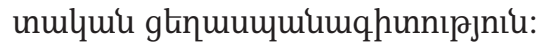

ㄴ. hnuunh huugt' manukyan.suren@genocide-museum.am

Suren A. Manukyan, PhD in History, orientalist, Head of the Comparative Genocide Studies Department named after Vahakn Dadrian, Armenian Genocide Museum-Institute Foundation, and Head of the Department of Genocide Studies at Institute of Armenian Studies, Yerevan State University.

Research fields - genocide perpetrators studies, comparative genocide studies.

E-mail: manukyan.suren@genocide-museum.am

Сурен А. Манукян, канд. ист. наук, востоковед, заведующий Отделом сравнительного изучения геноцидов им. Ваагна Дадряна Фонда "Музей-институт Геноцида армян," заведующий Отдела геноцидоведения Института арменоведения Ереванского государственного университета.

Область исследований - изучение преступников, виновных в осуществлении геноцида, сравнительное изучение геноцидов.

Эл. почта: manukyan.suren@genocide-museum.am 